\title{
Plasma Membrane and Organellar Targets of STIM1 for Intracellular Calcium Handling in Health and Neurodegenerative Diseases
}

\author{
Valentina Tedeschi $^{1}$, Daniele La Russa ${ }^{2} \mathbb{D}$, Cristina Franco ${ }^{3}$, Antonio Vinciguerra ${ }^{1}$, Diana Amantea ${ }^{2} \mathbb{D}$ \\ and Agnese Secondo $1, *$ (D) \\ 1 Department of Neuroscience, Division of Pharmacology, Reproductive and Odontostomatological Sciences, \\ School of Medicine, University of Naples “Federico II”, 80131 Napoli, Italy; valentina.tedeschi@unina.it (V.T.); \\ antonio.vinciguerra@unina.it (A.V.) \\ 2 Section of Preclinical and Translational Pharmacology, Department of Pharmacy, Health and Nutritional \\ Sciences, University of Calabria, 87036 Rende, Italy; daniele.larussa@unical.it (D.L.R.); \\ diana.amantea@unical.it (D.A.) \\ 3 Department of Science and Technology—DST, Division of Pharmacology, University of Sannio, \\ 82100 Benevento, Italy; cristina.franco@unisannio.it \\ * Correspondence: secondo@unina.it; Tel.: +39-081-746-3335
}

check for updates

Citation: Tedeschi, V.; La Russa, D.; Franco, C.; Vinciguerra, A.; Amantea, D.; Secondo, A. Plasma Membrane and Organellar Targets of STIM1 for Intracellular Calcium Handling in Health and Neurodegenerative Diseases. Cells 2021, 10, 2518. https://doi.org/10.3390/ cells10102518

Academic Editor: Isabella Derler

Received: 30 July 2021

Accepted: 21 September 2021

Published: 23 September 2021

Publisher's Note: MDPI stays neutral with regard to jurisdictional claims in published maps and institutional affiliations.

Copyright: (c) 2021 by the authors. Licensee MDPI, Basel, Switzerland. This article is an open access article distributed under the terms and conditions of the Creative Commons Attribution (CC BY) license (https:// creativecommons.org/licenses/by/ $4.0 /)$.

\begin{abstract}
Located at the level of the endoplasmic reticulum (ER) membrane, stromal interacting molecule 1 (STIM1) undergoes a complex conformational rearrangement after depletion of ER luminal $\mathrm{Ca}^{2+}$. Then, STIM1 translocates into discrete ER-plasma membrane (PM) junctions where it directly interacts with and activates plasma membrane Orai1 channels to refill ER with $\mathrm{Ca}^{2+}$. Furthermore, $\mathrm{Ca}^{2+}$ entry due to Orai1/STIM1 interaction may induce canonical transient receptor potential channel 1 (TRPC1) translocation to the plasma membrane, where it is activated by STIM1. All these events give rise to store-operated calcium entry (SOCE). Besides the main pathway underlying SOCE, which mainly involves Orai1 and TRPC1 activation, STIM1 modulates many other plasma membrane proteins in order to potentiate the influx of $\mathrm{Ca}^{2+}$. Furthermore, it is now clear that STIM1 may inhibit $\mathrm{Ca}^{2+}$ currents mediated by L-type $\mathrm{Ca}^{2+}$ channels. Interestingly, STIM1 also interacts with some intracellular channels and transporters, including nuclear and lysosomal ionic proteins, thus orchestrating organellar $\mathrm{Ca}^{2+}$ homeostasis. STIM1 and its partners/effectors are significantly modulated in diverse acute and chronic neurodegenerative conditions. This highlights the importance of further disclosing their cellular functions as they might represent promising molecular targets for neuroprotection.
\end{abstract}

Keywords: $\mathrm{Ca}^{2+}$ homeostasis; lysosomes; endoplasmic reticulum (ER); $\mathrm{Ca}^{2+}$-storing organelles; amyotrophic lateral sclerosis (ALS)

\section{Introduction}

Stromal interacting molecule 1 (STIM1), a single transmembrane-spanning domain protein mainly residing in the endoplasmic reticulum (ER), is the unique $\mathrm{ER} \mathrm{Ca}^{2+}$ sensor deputed to $\mathrm{ER} \mathrm{Ca}^{2+}$ refilling [1]. Historically, STIM1 was identified in 2005 by RNA interference-based screening of proteins with known signaling motifs [2]. Molecularly, STIM1 residing into the organelle senses luminal $\mathrm{Ca}^{2+}$ concentration by its $\mathrm{N}$-terminus with a low affinity with an apparent dissociation constant $\left(\mathrm{K}_{\mathrm{d}}\right)$ of $\sim 0.2-0.6 \mathrm{mM}$ [3]. This low affinity is due to the high $\mathrm{Ca}^{2+}$ levels within the organelle allowing the function of STIM1 as a unique ER $\mathrm{Ca}^{2+}$ sensor. When $\mathrm{ER} \mathrm{Ca}^{2+}$ diminishes, STIM1 may diffuse to the plasma membrane regions where it interacts with the channel Orai1 through its C-terminal domain, after the unfolding of the EF-hand-sterile alpha motif (SAM). This interaction triggers a localized increase in cytoplasmic $\mathrm{Ca}^{2+}$ that induces SERCA pump activation to refill ER of $\mathrm{Ca}^{2+}$. Two alternative splicing variants of STIM1 have been cloned: the long isoform named STIM1L with an extra 106 amino acids on its C-terminus, and the 
short 90-kDa STIM1 molecule named STIM1S. STIM1L is highly expressed in skeletal muscle as well as in several other tissues, including spleen, lungs, liver, brain and heart but not in the kidney. In human myotubes, STIM1L is expressed during myogenesis in the proximity to the PM, thus mediating a fast SOCE [4]. STIM1L displays a stronger propensity towards canonical transient receptor potential channel 1 (TRPC1) since it is more prone to open this channel [5]. Very recently, a neuronal splice variant named STIM1B has been cloned; it is selectively targeted to presynaptic ER and is useful to replenish synaptic vesicles after $\mathrm{Ca}^{2+}$ depletion [6]. On the other hand, STIM2 induces a weak activation of Orai1 [7] that minimally contributes to $\mathrm{Ca}^{2+}$ entry and prompts a limited $\mathrm{Ca}^{2+}$-dependent NFAT1 activation [8]. In this respect, a functional coupling between STIM2 and STIM1 has been proposed. In fact, when ER $\mathrm{Ca}^{2+}$ stores are maximally depleted, STIM2 targets Orai1/STIM1 complex to ER-PM junctions promoting assembly of the channel with the AKAP79/calcineurin signaling complex that promotes NFAT1 activation [8]. However, STIM1 plays the major role in clustering and activating Orai1. Therefore, STIM1 activation governs $\mathrm{ER} \mathrm{Ca}^{2+}$ refilling through store-operated calcium entry (SOCE), a ubiquitous plasma membrane mechanism first described by Jim Putney in 1986 [9]. SOCE provides $\mathrm{Ca}^{2+}$ signals to regulate critical cell functions in many tissues after the generation of inositol 1,4,5-triphosphate $\left(\mathrm{IP}_{3}\right)$ in response to receptor stimulation and the release of $\mathrm{Ca}^{2+}$ from the ER. The molecular components involved in the process remained uncharacterized for several years. A major advancement in the field came with the identification of the calcium release-activated calcium (CRAC) channel mediating the highly $\mathrm{Ca}^{2+}$ selective current $\left(\mathrm{I}_{\mathrm{CRAC}}\right)$ in mast cells and $\mathrm{T}$ lymphocytes [10-16]. Therefore, $\mathrm{Ca}^{2+}$ influx mediated by CRAC channels is called SOCE, because it is regulated by the filling state of $\mathrm{ER} \mathrm{Ca}^{2+}$ stores. ICRAC is a non-voltage activated, inwardly rectifying current, highly selective for $\mathrm{Ca}^{2+}$. Accordingly, it displays a $\mathrm{Ca}^{2+}: \mathrm{Na}^{+}$permeability ratio of $1000: 1[17,18]$. Of note, the single-channel conductance of CRAC is small as compared with that of other plasma membrane channels, and it has been estimated in about $24 \mathrm{fS}$ in Jurkat T cells [18].

Thanks to the effort of the scientific community, much is actually known about the regulatory mechanisms of SOCE (i.e., arrangement, dynamics, stoichiometry of SOCE molecular components) not only in non-excitable cells, where it is the primary $\mathrm{Ca}^{2+}$ influx pathway, but also in neuronal cells. However, once the role of STIM1 has been established, elucidating the other molecular components of SOCE proved to be a challenging endeavor for almost two decades. A number of proteins have been proposed to interact with STIM1, which are located both in the plasma membrane and at different intracellular levels. Some of these proteins may be considered as molecular partners of STIM1 and include Orai, TRPC channels, L-type voltage-dependent $\mathrm{Ca}^{2+}$ channels, plasma membrane $\mathrm{Ca}^{2+}$-ATPase (PMCA), exportin1, transportin1, SERCA2, SERCA3, etc. On the other hand, many modulators of SOCE, including the myelin basic protein Golli, and some scaffold proteins helping STIM1 to interact with its partners have also been described. A complex cooperation among these molecular components occurs in different parts of the cell to orchestrate intracellular $\mathrm{Ca}^{2+}$ homeostasis. Of note, this equilibrated cooperation may be altered during neurodegenerative disorders, thus causing neuronal death.

Molecularly, after store depletion, STIM1 interacts with the above-mentioned proteins, directly or indirectly through specific scaffold proteins. For instance, the SOCE-mediated cytosolic $\mathrm{Ca}^{2+}$ increase is primarily sustained by the direct activation of Orai1 by STIM1 and then by the inhibition of PMCA activity by STIM1-TMEM20 complex (see Section 4 for more details). When ER $\mathrm{Ca}^{2+}$ is refilled by SERCA [19], Orai1 and STIM1 dissociate and return to their resting state. This mechanism may be altered under pathological conditions through the dysregulation of both the expression and the function of STIM1 partners, thus impairing the outcomes of their interaction. 


\section{Plasma Membrane Targets of STIM1}

\subsection{Orai and TRPC1}

Depleting ER $\mathrm{Ca}^{2+}$ store promotes the activation of different types of $\mathrm{Ca}^{2+}$ currents, fostering the idea that several channels and regulatory proteins may be involved in the modulation of SOCE. However, the main mechanism underlying SOCE is the interaction between STIM1 and Orai1 associated with CRAC currents (i.e., ICRAC) [13]. Molecularly, the activation of Orai1 is elicited by the interaction with the STIM1-Orai-activating region (SOAR) in the C-terminal region of STIM1 [20]. There are two homologs of mammalian Orai1, namely Orai2 and Orai3, all generating SOCE [21]. Furthermore, two splice variants of Orai1 have been found: the 301 amino acids Orai1 $\alpha$ and the short variant Orai1 $\beta$, both ubiquitously expressed [22]. Interestingly, the relevance of Orai components in the process of SOCE is testified by the fact that Orai1, Orai2 and Orai3 were named after the three Horae (hours), Eunomia, Dike, Eirene, who-in Greek mythology—were the guardians of the gates of Olympus [23]. Interestingly, the $\mathrm{Ca}^{2+}$ selectivity of CRAC channels is not an intrinsic and immutable property of Orai1 but it is due to STIM1 gating. In fact, mutations of Orai1 may be a general mechanism for cells to tune $\mathrm{Ca}^{2+}$ and $\mathrm{Na}^{+}$entry in a STIM1-independent manner. However, STIM1 binding modifies the structural features of the mutant channel pore, bestowing the classical $\mathrm{Ca}^{2+}$ selectivity of CRAC channels [24]. Another important consideration is that Orai1 may form heteropentameric complexes with Orai3 to function as arachidonate-regulated $\mathrm{Ca}^{2+}$ (ARC) channel, a store-independent channel that is activated by STIM1 located in the plasma membrane [25,26]. Interestingly, only the Orai1 $\alpha$ splice variant seems to play a functional role in the ARC channels [27].

The Drosophila transient receptor potential (TRP) channel was the first proposed candidate of SOCE $[28,29]$, and the TRP canonical 1 (TRPC1) was the first mammalian member of the TRPC channel family to be cloned [30,31]. TRPC1 interacts with and is activated by STIM1 by means of an electrostatic interaction thus aggregating with Orai1 and STIM1 within the same ER-PM junctions [32]. However, TRPC1 recruitment is dependent on Orai1 activity [33]. In fact, Orai1-mediated $\mathrm{Ca}^{2+}$ entry allows the translocation of TRPC1 into the plasma membrane where it is activated by STIM1 [34,35]. Despite the impressive data supporting the involvement of TRPC1 in SOCE, the biophysical features of the current associated with TRPC1 do not match with I CRAC. For that reason, the TRPC1associated current was named store-operated calcium current (ISOC) to distinguish it from

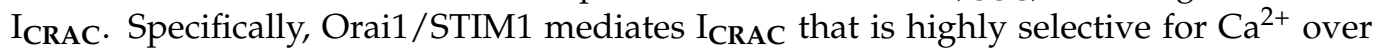
$\mathrm{Na}^{+}\left(\mathrm{P}_{\mathrm{Ca}} / \mathrm{P}_{\mathrm{Na}} \sim 1\right)$, while TRPC1/STIM1 mediates Isoc, a cationic current with a poor $\mathrm{Ca}^{2+}$ selectivity. Accordingly, it shows a calcium over sodium ratio between 10 and 40 $\left(\mathrm{P}_{\mathrm{Ca}} / \mathrm{P}_{\mathrm{Na}} \sim 10-40\right)$ [36]. Furthermore, $\mathrm{CRAC}$ single-channel conductance has been estimated in about $24 \mathrm{fS}$ in Jurkat $\mathrm{T}$ cells [18] while CPA-evoked I SOC $_{\text {Sad }}$ a unitary conductance of $2.5 \pm 0.3 \mathrm{pS}$ in portal vein smooth muscle cells [36]. Interestingly, Orai1 is necessary for TRPC1-mediated I $\mathrm{SOC}_{\text {, }}$ since knocking down both, or expressing dominant negative Orail constructs inhibits ISOC. Therefore, the entry of $\mathrm{Ca}^{2+}$ through I IRAC channels recruits TRPC1 to the plasma membrane that, once activated by STIM1, may mediate ISOC [37].

TRPC1 may associate with TRPC3, TRPC4 and TRPC5 subunits to form a channel with different sensitivity to STIM1 [38]. Interestingly, TRPC may also be activated independently from STIM1 by a G protein-coupled receptor [39]. In any case, the two Orai1 variants can be used as functional subunits of both CRAC and SOC channels [27].

TRPC1-mediated $\mathrm{Ca}^{2+}$ entry is associated with the regulation of many relevant pathophysiological functions in different tissues, including gene expression, smooth, skeletal, and cardiac muscle function, proliferation, migration, fluid secretion, mast cell degranulation, platelet aggregation and $\mathrm{T}$ cell activation [40-43]. Furthermore, dysregulated activity of TRPC1 may contribute to the progression of various types of cancers, including breast cancer, pancreatic cancer, glioblastoma, lung cancer, hepatic cancer, multiple myeloma and thyroid cancer [44]. Interestingly, most of these functions are associated with the so-called TRPC1 channelosome due to its interaction with other proteins [40]. TRPC1 channelosome 
contains other TRPC channel isoforms and also $\mathrm{Ca}^{2+}$ signaling proteins such as $\mathrm{Ca}_{\mathrm{V}}-1$, HOMER, IP ${ }_{3} R, P L C, G_{\alpha q / 11}$ and PMCA in order to mediate a plethora of cell functions [40].

\subsection{Plasma Membrane $\mathrm{Ca}^{2+}$-ATPase (PMCA)}

During $\mathrm{T}$ cell activation, STIM1 regulates intracellular $\mathrm{Ca}^{2+}$ clearance through the functional interaction with the plasma membrane $\mathrm{Ca}^{2+}$-ATPase (PMCA) $[45,46]$. In this way, STIM1 is able to govern intracellular $\mathrm{Ca}^{2+}$ homeostasis in T cells. Of note, elevated intracellular $\mathrm{Ca}^{2+}$ levels with specific spatiotemporal features play a critical role in the activation of the $\mathrm{Ca}^{2+}$-dependent nuclear factor of activated T cells (NFAT). In this respect, the interaction between STIM1 and PMCA regulates NFAT-dependent cytokine production via transcriptional events in Jurkat $\mathrm{T}$ cells $[45,46]$. However, the correlation between STIM1 expression and inhibition of $\mathrm{Ca}^{2+}$ clearance is a non-linear phenomenon, thus suggesting the involvement of additional, but yet unknown, players. Therefore, PMCA could be considered as a member of a growing list of STIM1 targets, together with Orai $[21,47,48]$, TRPC $[34,49,50]$ and $C_{V} 1.2[51,52]$ proteins. However, STIM1 modulates PMCA function also through its partner POST, which preferentially associates with PMCA4b over PMCA4a isoforms. In this latter case, STIM1/POST potentiates, rather than inhibits, PMCA4 function [53]. Interestingly, POST prevents PMCA4 from STIM1-mediated inhibition, determining the proper coupling of PMCA4 to Orai1. This promotes $\mathrm{Ca}^{2+}$ entry mechanism and NFAT activation in Jurkat T cells [53].

\section{3. $\mathrm{Na}^{+} / \mathrm{K}^{+}$ATPase}

A role of STIM1 in determining $\mathrm{Ca}^{2+}$-dependent $\mathrm{Na}^{+} / \mathrm{K}^{+}$ATPase downregulation in isolated alveolar epithelial cells exposed to hypoxia has been suggested [54]. In fact, during hypoxia, calcium entry via CRAC channels triggers $\mathrm{Na}^{+} / \mathrm{K}^{+}$ATPase downregulation, producing alveolar epithelial dysfunction. STIM1 knockdown prevents $\mathrm{Na}^{+} / \mathrm{K}^{+}$ATPase hypofunction, thus protecting hypoxic cells from fluid reabsorption impairment. However, a direct interaction between STIM1 and $\mathrm{Na}^{+} / \mathrm{K}^{+}$ATPase remains unknown.

\subsection{L-Type Voltage-Gated $\mathrm{Ca}^{2+}$ Channels (VGCCs)}

L-type voltage-gated $\mathrm{Ca}^{2+}$ channels (VGCCs) are interesting targets of STIM1, whose modulation is different from that described so far. In rat cortical neurons and vascular smooth muscle cells, the depolarization-opening of L-type VGCC is inhibited by a STIM1dependent pathway [52]. SOAR is involved in the inhibition of L-type VGCC as observed for the conventional activation of Orai by STIM1. Furthermore, to control the activity of this channel for a longer period of time, STIM1 may also trigger its internalization. Interestingly, Orai1 co-localizes with STIM1 and L-type VGCC at ER-PM junctions after store depletion, thus suggesting the involvement of the plasma membrane component of SOCE in the modulation of L-type VGCC. However, since nonconductive Orai mutants may participate in the inhibition of L-type VGCC, the involvement of the Orai channel as a scaffold protein has been postulated. The same mechanism has been shown to occur for TRPC modulation [55]. With L-type VGCC being one of the main represented channels in excitable cells, the modification of STIM1-mediated inhibition of the channel may account for several pathogenetic mechanisms not fully clarified yet.

\section{Intracellular Targets of STIM1}

\subsection{SERCA2A and SERCA3}

Among the intracellular targets of STIM1 (Table 1), the sarco/endoplasmic reticulum $\mathrm{Ca}^{2+}$ ATPase (SERCA) pump is probably the most relevant. In fact, the inward current generated by STIM1/Orai interaction continuously triggers the replenishment of $\mathrm{ER} \mathrm{Ca}^{2+}$ store through SERCA activity [19]. In this regard, the interaction between STIM1 and SERCA2A is mainly involved in ER $\mathrm{Ca}^{2+}$ refilling through Orai1 recruitment [56]. However, besides its role in SOCE, STIM1 is also involved in acidic $\mathrm{Ca}^{2+}$ store refilling through the interaction with SERCA3 [57]. This occurs in platelets in a SOC-independent way after 
thrombin or thapsigargin stimulation. Of note, STIM1-SERCA3 refilling is altered in platelets from type 2 diabetic patients, thus resulting in higher intracellular $\mathrm{Ca}^{2+}$ levels, platelet hyperactivity and cardiovascular defects [57].

\subsection{TRPML1}

Global intracellular $\mathrm{Ca}^{2+}$ homeostasis depends on a complex and very well integrated network among plasma membrane ionic proteins and intracellular $\mathrm{Ca}^{2+}$-storing organelles, also interacting each other through discrete membrane contact sites [58,59]. Lysosomes, the tiny acidic organelles mainly deputed to cellular catabolic activities [60] and autophagy [61], are now considered important $\mathrm{Ca}^{2+}$-storing compartments interacting with ER and mitochondria to maintain intracellular $\mathrm{Ca}^{2+}$ homeostasis under both physiological and pathological conditions [62,63]. Lysosomal $\mathrm{Ca}^{2+}$ could be released by intracellular cues, including nicotinic acid adenine dinucleotide phosphate (NAADP), acting on twopore channels [64], and the lysosome-enriched phosphoinositide $\mathrm{PI}(3,5) \mathrm{P}_{2}$, stimulating TRPML1 [65]. The local $\mathrm{Ca}^{2+}$ release from lysosomesis involved in the maintenance of global $\mathrm{Ca}^{2+}$ signaling through the interaction with the ER $[66,67]$. Therefore, it is plausible that a local machinery may connect the two organelles to allow the exchange of $\mathrm{Ca}^{2+}$ ions. In this respect, the ER $\mathrm{Ca}^{2+}$ sensor STIM1 has been identified as a fine regulator of TRPML1 activity $[68,69]$. Thus, the interaction between STIM1 and TRPML1 allows the regulation of both lysosomal and $\mathrm{ER} \mathrm{Ca}^{2+}$ homeostasis. This may occur through a bidirectional interplay between the two organelles, both able to refill with $\mathrm{Ca}^{2+}$ ions in both physiological and pathological conditions [69].

\subsection{Nuclear Proteins}

At the nuclear level, some proteins belonging to the nuclear transporters karyopherins have also been found to interact with STIM1 [70,71]. However, the meaning of this interaction remains unknown. In HeLa cells, the association between STIM1 and the nuclear carrier proteins exportin 1 and transportin 1 may occur under physiological conditions in a $\mathrm{Ca}^{2+}$-independent way. In fact, this event is observed even in the presence of EDTA [70].

However, the interaction between STIM1 and importins and exportins requires the scaffolding molecule POST (see Section 4 for more details). Interestingly, on $\mathrm{ER} \mathrm{Ca}^{2+}$ depletion, POST strongly binds to the ER $\mathrm{Ca}^{2+}$ sensor and translocates in proximity to the nuclear envelope, thus suggesting a possible role for $\mathrm{ER} \mathrm{Ca}^{2+}$ depletion in the modulation of nuclear import/export activity [71]. 
Table 1. STIM1 targets at plasma membrane (in blue) and intracellular (in green) level.

\begin{tabular}{|c|c|c|c|c|}
\hline STIM1 Target & Localization & Effect of the Interaction & References & \\
\hline Orai & Plasma membrane & $\mathrm{ER} \mathrm{Ca}^{2+}$ refilling through SOCE & {$[9,21,47,48]$} & \multirow{5}{*}{ 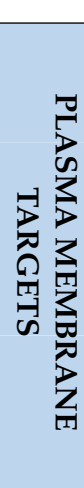 } \\
\hline TRPC1 & Plasma membrane & $\begin{array}{c}\mathrm{ER} \mathrm{Ca}^{2+} \text { refilling through SOCE } \\
\text { in an Orai1-dependent way }\end{array}$ & {$[28,29,32-35,49,50,57]$} & \\
\hline PMCA & Plasma membrane & $\begin{array}{l}\text { Regulation of intracellular } \mathrm{Ca}^{2+} \\
\text { homeostasis in T cells; } \\
\text { regulation of NFAT-dependent } \\
\text { cytokine production in Jurkat T } \\
\text { cells }\end{array}$ & {$[45,46,53]$} & \\
\hline $\mathrm{Na}^{+} / \mathrm{K}^{+}$ATPase & Plasma membrane & $\begin{array}{c}\mathrm{Na}^{+} / \mathrm{K}^{+} \text {ATPase } \\
\text { downregulation during hypoxia } \\
\text { in alveolar epithelial cells }\end{array}$ & [54] & \\
\hline L-type VGCC & Plasma membrane & Inhibition of L-type VGCC & {$[51,52]$} & \\
\hline SERCA2A & Endoplasmic reticulum & $\begin{array}{c}\mathrm{ER} \mathrm{Ca}^{2+} \text { refilling through Orai1 } \\
\text { recruitment }\end{array}$ & [56] & \multirow{5}{*}{ 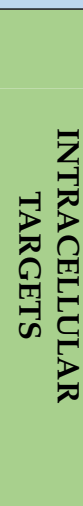 } \\
\hline SERCA3 & Endoplasmic reticulum & $\begin{array}{c}\text { Acidic } \mathrm{Ca}^{2+} \text { store refilling in } \\
\text { platelets in a SOC-independent } \\
\text { way }\end{array}$ & [57] & \\
\hline TRPML1 & Lysosome & $\begin{array}{l}\text { Regulation of lysosomal and ER } \\
\mathrm{Ca}^{2+} \text { homeostasis }\end{array}$ & {$[68,69]$} & \\
\hline $\begin{array}{l}\text { Exportin } 1 \text { and } \\
\text { transportin } 1\end{array}$ & Nuclear envelope & $?$ & [70] & \\
\hline $\begin{array}{l}\text { Importins and } \\
\text { exportins }\end{array}$ & Nuclear envelope & $\begin{array}{l}\text { Possible role in the modulation } \\
\text { of nuclear import/export, } \\
\text { through the scaffold protein } \\
\text { TMEM20/POST }\end{array}$ & [71] & \\
\hline
\end{tabular}

\section{STIM1 Scaffold Proteins}

STIM1 can modulate several ionic partners directly or through scaffold proteins enabling the $\mathrm{Ca}^{2+}$ sensor to interact with multiple transporters (Table 2). In this respect, the 10-transmembrane-spanning segment protein TMEM20 located at ER level has been considered the most important STIM1 protein mediator [71]. In fact, it has also been called the partner of stromal interaction molecule 1 (POST), since it is relevantly involved in the binding of STIM1 to plasma membrane proteins including Orai1, PMCA, SERCAs, $\mathrm{Na}^{+} / \mathrm{K}^{+}$ ATPase, as well as nuclear proteins located at the nuclear envelope such as importins- $\beta$ and exportins. At the plasma membrane level, POST-Orail binding is store depletionindependent. POST downregulation or overexpression does not substantially affect Orai1mediated CRAC, thus suggesting the possibility that POST could modulate Orai1 activity in response to other physiological stimuli, independently from store depletion events. Interestingly, POST knockdown determines an increase in PMCA activity in store-depleted cells in which the STIM1-POST complex is bound to PMCA [71]. This suggests that the interaction between STIM1-POST and PMCA reduces the pump $\mathrm{Ca}^{2+}$ extrusion, thus determining a sustained cytosolic $\mathrm{Ca}^{2+}$ elevation.

For instance, suppressing TMEM20/POST expression through miR-150 determines an increase in intracellular $\mathrm{Ca}^{2+}$ levels after TCR stimulation in $\mathrm{CD} 8^{+} \mathrm{T}$ cells. Since this is essential to induce the expression of activation-associated genes, miR-150-induced reduction in TMEM20 allows naïve $\mathrm{CD} 8^{+} \mathrm{T}$ cells to express anergy-inducing genes, such as Casitas B lineage lymphoma $b$ (Cbl-b), Egr2 and p27. These findings suggest the central role of TCR-mediated intracellular $\mathrm{Ca}^{2+}$ regulation in naïve $\mathrm{CD}^{+} \mathrm{T}$ cells [72].

Another important STIM1-interacting protein is the microtubular protein EB1, involved in the formation of STIM1-SERCA2A complex [56]. By interacting with this protein, STIM1 may recruit SERCA2A after Orai1 association thus replenishing the intracellular $\mathrm{Ca}^{2+}$ store by the generation of an inward current creating a local microdomain. After the complete refilling, the complex dissociates, thus silencing the inward current. Upon store depletion, STIM1 becomes strongly bound to the POST-targeted molecules SERCA, PMCA 
and $\mathrm{Na}^{+} / \mathrm{K}^{+}$ATPase, as well as to the nuclear transporters, importins- $\beta$ and exportins. Store depletion-dependent STIM1 binding to SERCA2 [56] and some karyopherins [70] have been reported previously.

\section{Molecular Modulators of STIM1}

After ER $\mathrm{Ca}^{2+}$ depletion, a full array of adaptor proteins allows STIM1-Orai association with optimal efficiency. Among these adaptors, CRACR2A [73], septins [74], $\alpha$ SNAP [75] and STIMATE $[76,77]$ have distinct inter-dependent roles. For instance, when ER luminal $\mathrm{Ca}^{2+}$ decreases, STIMATE interacts with the juxtamembrane coiled-coil region termed $\mathrm{CC} 1$ promoting the STIM1 transition to its active conformation. Then, septins target Orai1 to ER-PM junctions where $\alpha$ SNAP regulates STIM-Orai stoichiometry. Among the numerous negative regulators of STIM1 (Table 2) [78,79], the ER resident protein SARAF (SOCE-associated regulatory factor) plays a fundamental role in facilitating the $\mathrm{Ca}^{2+}$-dependent slow inactivation of CRAC channels after the interaction with the cytoplasmic C-terminus of STIM1 [80]. Thus, SARAF contributes to protect cells from $\mathrm{Ca}^{2+}$ overfilling [80,81]. However, SARAF may act in a dualistic way: a brief treatment with thapsigargin significantly reduces the association between SARAF and STIM1, promoting a transient association between SARAF and Orai1 with the aim to activate the plasmalemmal channel. This contributes to shape cytosolic $\mathrm{Ca}^{2+}$ signals, increasing the content of intracellular $\mathrm{Ca}^{2+}$ stores $[80,81]$. Therefore, in the absence of STIM1, SARAF may exert a direct stimulation of Orai1 activity, thus restoring basal $\mathrm{ER} \mathrm{Ca}^{2+}$ refilling in a situation of ER depletion [82]. Another negative regulator of STIM1 is the fragment P100 of polycystin1 , the gene product of PKD1 whose mutations result in autosomal dominant polycystic kidney disease (ADPKD). Interestingly, only the cleavage product P100 reduces SOCE via direct inhibition of STIM1 translocation [83]. Furthermore, a 58-kDa thiol oxidoreductase, ERp57, exerts a modulatory role on SOCE by regulating STIM1 oligomerization [84]. Of note, thrombocythemia or primary myelofibrosis patients carry a somatic mutation of the calreticulin gene determining defective interactions between mutant calreticulin, ERp57, and STIM1. This event may activate SOCE and generates non-physiological spontaneous cytosolic $\mathrm{Ca}^{2+}$ influx [85].

An interesting study identified stanniocalcin 2 (STC2), a secreted glycoprotein involved in phosphate metabolism, as a negative regulator of SOCE [86]. Of note, stanniocalcin 2 is required for thrombin-induced STIM1-Orai1 interaction and the subsequent SOCE in platelets [87]. Interestingly, platelets from STC2-deficient mice showed enhanced aggregation through the increase in Orai3, but not TRPC3 and TRPC6 [87]. STIM1 can directly interact with microtubules (MT) plus end-binding protein EB1 that plays a role in ER tubulation [88]. Besides its role as scaffold in the formation of STIM1 complex, EB1 binding is also considered a trapping mechanism restricting STIM1 to ER-PM junctions, thus preventing excessive SOCE and ER Ca ${ }^{2+}$ overload [89]. Finally, it has been reported that Golli-BG21, a member of the MBP (myelin basic protein) family of proteins, regulates SOCE in Tcells and oligodendrocyte precursors. Specifically, Golli interacts with the C-terminal domain of STIM1, reducing the activity of SOCCs [90].

Table 2. Scaffold proteins and modulators of STIM1.

\begin{tabular}{|c|c|c|c|}
\hline STIM1 Modulator & Localization & Effect & References \\
\hline TMEM20/POST & $\begin{array}{l}\text { ER membrane; } \\
\text { plasma membrane } \\
\text { (minor fraction) }\end{array}$ & $\begin{array}{l}\text { Scaffold protein involved in the binding of } \\
\text { STIM1 to plasma membrane proteins (i.e., } \\
\text { Orai1, PMCA, SERCAs, } \mathrm{Na}^{+} / \mathrm{K}^{+} \text {ATPase) and } \\
\text { nuclear membrane proteins (importins and } \\
\text { exportins) }\end{array}$ & [71] \\
\hline $\begin{array}{l}\text { SARAF } \\
\text { (SOCE-associated } \\
\text { regulatory factor) }\end{array}$ & ER membrane & $\begin{array}{l}\text { It protects cells from } \mathrm{Ca}^{2+} \text { overfilling by } \\
\text { promoting the } \mathrm{Ca}^{2+} \text {-dependent slow } \\
\text { inactivation of CRAC channels after the } \\
\text { interaction with STIM1 }\end{array}$ & {$[80,81]$} \\
\hline $\begin{array}{l}\text { Fragment } \mathrm{P} 100 \text { of } \\
\text { polycystin-1 }\end{array}$ & $?$ & $\begin{array}{l}\text { Reduction in SOCE via direct inhibition of } \\
\text { STIM1 translocation }\end{array}$ & [83] \\
\hline ERp57 & ER lumen & $\begin{array}{l}\text { Negative modulation of SOCE via regulation } \\
\text { of STIM1 oligomerization }\end{array}$ & [84] \\
\hline
\end{tabular}


Table 2. Cont.

\begin{tabular}{cccc}
\hline STIM1 Modulator & Localization & Effect & References \\
\hline EB1 & Microtubules & $\begin{array}{c}\text { It restricts STIM1 to ER-PM junctions, thus } \\
\text { preventing excessive SOCE and ER Ca }{ }^{2+} \\
\text { overload }\end{array}$ & $\begin{array}{c}\text { By interacting with the } \\
\text { [89] }\end{array}$ \\
\hline Golli & Cell body, nucleus and & processes & $\begin{array}{c}\text { C-terminal domain of STIM1, it negatively } \\
\text { regulates the activity of SOCCs }\end{array}$ \\
\hline
\end{tabular}

\section{STIM1 Partners in Neurodegenerative Diseases}

The involvement of STIM1 (and its partners) in neuronal injury has been demonstrated in diverse acute and chronic degenerative conditions (Figure 1). Increased STIM1 expression precedes cell death of cortical neurons in rats exposed to lateral head rotational injury [92]. Similarly, traumatic brain injury triggers elevation of STIM1 expression that contributes to apoptotic cells death by upregulating metabotropic glutamate receptor (mGluR)1-dependent $\mathrm{Ca}^{2+}$ signalling [93].

Proximity ligation assay, co-immunolocalization and co-immunoprecipitation experiments performed either in situ or in vitro disclosed the existence of a physical interaction between STIM1 or STIM2 and the N-methyl-D-aspartate receptor (NMDAR)2 subunits, NR2A and NR2B [94]. The authors hypothesized that $\mathrm{ER} \mathrm{Ca}^{2+}$ depletion, that typically facilitates STIM-Orai1 interaction, also reduces the formation of hetero-complexes, mainly composed of STIM1-NR2B and STIM2-NR2A, being the former instrumental to allow STIM1 translocation to the plasma membrane. Therefore, STIMs can modulate NMDARmediated $\mathrm{Ca}^{2+}$ signalling by directly interacting with receptor subunits. Alternatively, in hippocampal neurons, exposure to glutamate prompts $\mathrm{Ca}^{2+}$ influx through NMDARs and L-type VGCCs, resulting in the release of $\mathrm{Ca}^{2+}$ from the ER and activation of STIM1 [95]. Thus, NMDAR stimulation activates STIM1 to directly regulate the structural plasticity of L-type VGCC-dependent dendritic spines [95].

Thus, dysfunctions of STIM and NMDAR have been suggested to be involved in the pathogenesis of neurodegenerative diseases, although the mechanisms involved in the interplay between these two partners need to be further elucidated [96,97]. Overstimulation of NMDARs results in intracellular $\mathrm{Ca}^{2+}$ overload that underlies excitotoxic neuronal death in neurodegeneration occurring in brain ischemia, Huntington's disease (HD) and Alzheimer's disease (AD) [98-101]. In these contexts, targeting the mechanism that links NMDAR with STIM proteins might represent a promising neuroprotective strategy [95,102-104]. Accordingly, upregulating STIMs can protect against NMDA-induced dysfunctions of $\mathrm{Ca}^{2+}$ homeostasis [94]. In addition to its role in the regulation of NMDAR-mediated excitotoxic injury, STIM1 has also been shown to be involved (directly or indirectly through its partners/effectors) in detrimental mechanisms specifically activated under diverse neurodegenerative conditions (Figure 1).

Another issue that needs to be addressed when considering neurodegenerative diseases consists of evidence that $\mathrm{Ca}^{2+}$ channels are regulated by redox modifications of reactive cysteines typically induced through chemically (reactive oxygen species [ROS], $\mathrm{H}_{2} \mathrm{~S}$ ) or enzymatically driven electron transfer. Accordingly, SOCE is highly sensitive to redox modifications [105-108] and its function may be dramatically affected by the increased oxidative stress, typically occurring during acute (i.e., ischemic) or chronic neurodegenerative conditions. In fact, extracellular oxidants cause oxidative modifications of C195 in Orai1 and Orai2 and thereby inhibit SOCE [109], whereas redox regulation of STIM1 protein may occur through S-glutathionylation of the luminal C56 that causes $\mathrm{Ca}^{2+}$ store-independent clustering of STIM1 and, thus, activation of Orai channels [110]. Conversely, STIM2 oxidation has recently been shown to inhibit SOCE [111]. STIM1 function is also regulated by the ER oxidoreductase ERp57 via redox modulation of C49 and C56. The lack of these two residues caused inhibition of SOCE, whereas ERp57 knockdown 
caused its elevation [84]. Furthermore, studies have demonstrated that S-nitrosylation of STIM1 C49 and C56 interferes with STIM1 oligomerization and consequently leads to SOCE inhibition $[112,113]$. Thus, a better understanding of the crosstalk between redox modifications and STIM functions/interactions is crucial to understand the role of these calcium regulatory proteins in neurodegenerative diseases.
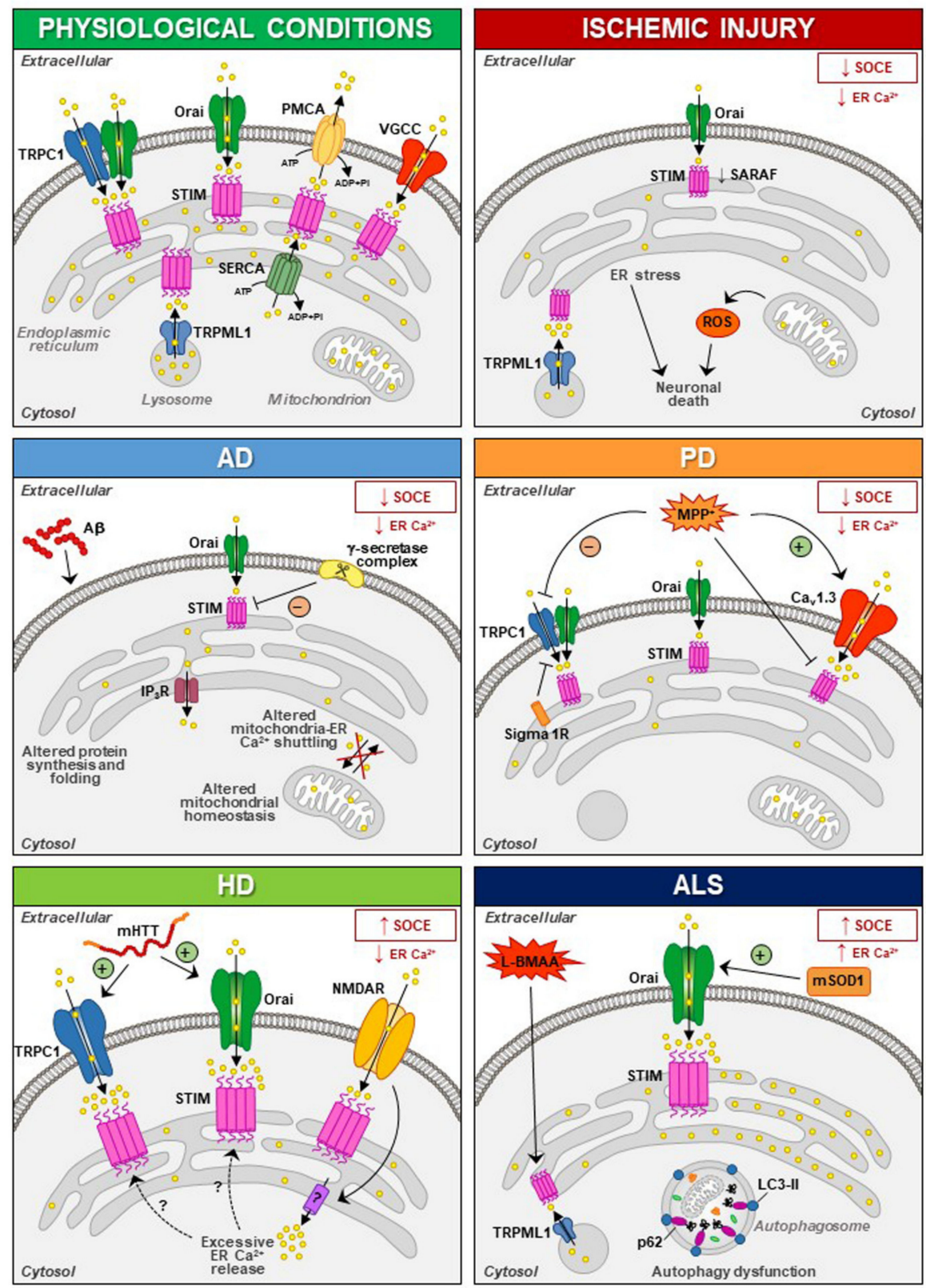

Figure 1. Schematic representation of STIM1 interactors at the plasma membrane and intracellular level in physiological conditions and during ischemic injury, Alzheimer's disease (AD), Parkinson's disease (PD), Huntington's disease (HD) and amyotrophic lateral sclerosis (ALS). Abbreviations: ER: endoplasmic reticulum, $\mathrm{IP}_{3} \mathrm{R}$ : inositol trisphosphate receptor, L-BMAA: $\beta$-methylamino-L-alanine, mHTT: mutant huntingtin protein, $\mathrm{MPP}^{+}$: 1-methyl-4-phenylpyridinium ion, $\mathrm{mSOD1}$ : mutant superoxide dismutase 1, NMDAR: N-methyl-D-aspartate receptor, PMCA: plasma membrane Ca ${ }^{2+}$-ATPase, ROS: reactive oxygen species, SARAF: SOCE-associated regulatory factor, SERCA: sarco/endoplasmic reticulum Ca ${ }^{2+} \mathrm{ATPase}$ TRPC1: canonical transient receptor potential channel 1, TRPML1: transient receptor potential mucolipin channel 1, VGCC: voltage-gated $\mathrm{Ca}^{2+}$ channel. 


\subsection{Ischemic Injury}

In ischemic brain injury, reduced expression of STIM1 and Orai1 has been suggested to underlie hypoxic/ischemic neuronal death in rats undergone focal ischemia and in primary cortical neurons exposed to oxygen and glucose deprivation (OGD) followed by reoxygenation [114]. In fact, under ischemic conditions, massive ER $\mathrm{Ca}^{2+}$ depletion may trigger neuronal death through ER stress, while $\mathrm{Ca}^{2+}$ refilling through SOCE underlies neuronal protection [115-117]. Accordingly, ischemic tolerance induced by ischemic preconditioning (IPC) has been reported to occur via the attenuation of ER stress response in ischemic neurons, while STIM1/Orai1-dependent $\mathrm{Ca}^{2+}$ refilling is considered a crucial mechanism involved in IPC-induced neuroprotection in rats [114,118]. STIM1 has also been shown to interact with the lysosomal $\mathrm{Ca}^{2+}$ channel TRPML1 to modulate lysosomal and $\mathrm{ER} \mathrm{Ca}{ }^{2+}$ content and their interplay is strongly affected by low oxygen conditions. Elevation of the expression of both proteins during OGD followed by $8 \mathrm{~h}$ of reoxygenation is coincident with ROS hyperproduction in cortical neurons [69]. This may result in persistent TRPML1 $\mathrm{Ca}^{2+}$ release and lysosomal $\mathrm{Ca}^{2+}$ loss. On the other hand, TRPML1 expression and activity are significantly reduced in cortical neurons exposed to IPC thus hampering lysosomal $\mathrm{Ca}^{2+}$ loss [69]. Thus, another mechanism by which STIM1 affects neuronal survival/death during hypoxia consists of the modulation of lysosomal TRPML1 channel activity to regulate organellar $\mathrm{Ca}^{2+}$ homeostasis.

Nevertheless, depending on the specific context, SOCE can also provide excessive $\mathrm{Ca}^{2+}$ influx, resulting in non-excitotoxic neuronal death that has been involved in ischemic damage $[119,120]$. In line with this concept, numerous in vitro studies have shown that STIM2 is implicated in ischemia-induced neuronal $\mathrm{Ca}^{2+}$ accumulation $[119,121,122]$ and deficiency of STIM2 confers protection against stroke in mice, likely through reduced $\mathrm{Ca}^{2+}$ accumulation into ER of neurons [119]. However, reduced expression of STIM1 and SARAF is associated with neuronal loss in the cortex of mice subjected to focal cerebral ischemia, whereas neuroprotection exerted by IPC prevents the reduction in SARAF (but not STIM1) induced by the insult [123]. This latter evidence could be interpreted as a compensatory mechanism to restore ER $\mathrm{Ca}^{2+}$ refilling in neurons in the absence of STIM1. An alternative hypothesis is based on the ability of SARAF to directly stimulate Orai1 activity, thus restoring basal ER $\mathrm{Ca}^{2+}$ refilling in a situation of ER depletion [82].

The "beneficial" role of STIM1 is also underscored by the evidence that in stroke-prone spontaneously hypertensive rat (SHRSP), the reduction in glial STIM1 is associated with the exaggerated sympathetic response leading to stroke. In fact, truncated STIM1 expressed in SHRSP astrocytes fails to interact with the $\mathrm{Ca}^{2+}$ channel TRPC1 located in the plasma membrane and impairs SOCE function [124], resulting in perturbation of downstream genes and neuronal network dysfunction. Further experimental work is needed to clarify the apparently dualistic role of STIM1 in the diverse cellular players (neurons vs. glia) of ischemic damage, also focusing on the modulatory role exerted by its partners (e.g., TRPML1, SARAF or TRPC1) to be exploited as molecular targets for ischemic stroke neuroprotection.

\subsection{Alzheimer's Disease (AD)}

Alzheimer's disease (AD) is the most common neurodegenerative disease, whereby the progressive neuronal demise is likely triggered by $\beta$-amyloid $(A \beta)$ peptide accumulation [125]. Nevertheless, pharmacological approaches targeting this process have failed to block disease progression [126-128], suggesting that mechanisms other than A $\beta$ peptide accumulation play a crucial pathobiological role.

Altered $\mathrm{Ca}^{2+}$ homeostasis is a very early sign of cell dysfunction in $\mathrm{AD}$ patients [129-132] and mutant presenilins (PSEN1 and PSEN2), associated with the majority of familial $\mathrm{AD}$ (FAD) cases, have been implicated in AD-related $\mathrm{Ca}^{2+}$ dysregulation, through different mechanisms, often independent from their $\gamma$-secretase activity [133]. These include altered $\mathrm{Ca}^{2+}$ homeostasis in ER, through increased sensitivity of inositol trisphosphate receptors $\left(\mathrm{IP}_{3} \mathrm{Rs}\right)$ [134-137], increased expression and activity of ryanodine 
receptors (RyRs) [138], negative regulation of SERCA pump [139,140] and most notably, decreased $\mathrm{Ca}^{2+}$ influx via SOCE [130,140-148]. Accordingly, SOCE is reduced in various FAD-PSEN expressing cells $[130,142]$, with both PSEN1 and PSEN2 involved in STIM1 downregulation [140]. PSENs modulate cellular levels of STIM proteins [149-151]; in fact, PSENs knockout in mouse embryonic fibroblasts results in increased STIM1 levels by affecting gene transcription or protein stability [149].

Alternatively, SOCE modulation has been ascribed to a $\gamma$-secretase-dependent mechanism, since (the transmembrane domain of) STIM1 represents a substrate of PSEN1containing $\gamma$-secretase complexes [141]. Notably, decreased STIM1 levels, correlated with the progression of neurodegeneration, were observed in the brain of sporadic AD patients [152]. This is also consistent with the evidence that STIM1 expression is reduced (through a $\gamma$-secretase-independent manner) in PSEN-expressing SH-SY5Y cells and human FAD fibroblasts [140]. Disruption of $\mathrm{Ca}^{2+}$ homeostasis is also triggered by amyloid precursor protein (APP) gene mutations that occur in FAD. Accordingly, APP-deficient cells display elevated resting $\mathrm{Ca}^{2+}$ levels in the ER and exhibit delayed translocation of STIM1 to Orai1 upon depletion of $\mathrm{Ca}^{2+}$ store [153]. More recently, Ludewig et al. have demonstrated that STIM1 and STIM2 are upregulated in double mutants lacking both APP and its homolog APLP2, resulting in impairment of $\mathrm{Ca}^{2+}$ handling, of ER refill and of synaptic plasticity [154].

These results strongly suggest that aberrant STIM1 levels contribute to the pathogenesis of FAD. Interestingly, downregulation of STIM1 may compromise its role in the regulation of $\mathrm{Ca}_{\mathrm{V}} 1.2$, thus affecting neuronal activity in $\mathrm{AD}$ [51,52]. In fact, reduced STIM1 levels occurring in various $\mathrm{AD}$ cell models underlie defective $\mathrm{Ca}^{2+}$ homeostasis and learning and memory impairment in a SOCE-independent manner. This includes regulation of ER refilling through mGluR1 and $5[155,156]$ and of synaptic plasticity [157], as well as $\mathrm{Ca}^{2+}$ overload through upregulation of L-type VGCCs and mitochondrial dysfunction [152]. A recent work has demonstrated that STIM1-deficient SH-SY5Y cells display reduced expression of the $\mathrm{IP}_{3}$ receptors type $3\left(\mathrm{IP}_{3} \mathrm{R} 3\right)$ that is, in turn, responsible for the low mitochondrial $\mathrm{Ca}^{2+}$ concentration $\left(\left[\mathrm{Ca}^{2+}\right]\right)$ and for the reduced efficiency of this organelle [158], which are common features in AD patients [159].

The resulting decrease of $\left[\mathrm{Ca}^{2+}\right]$ in intracellular stores, mainly ER and Golgi apparatus, contributes to neuronal demise by affecting protein synthesis and folding $[160,161]$, mitochondrial homeostasis $[162,163]$ and/or ER-mitochondrial $\mathrm{Ca}^{2+}$ shuttling that maintains ATP production and prevents autophagy [162-165]. Despite having a role in neuronal function, SOCE attenuation results in the reduction in mushroom spines occurring in hippocampal neurons from FAD-PSEN1 mutant mice [150], and in increased A $\beta$ generation in vitro $[146,166,167]$, further highlighting its role in AD pathobiology. SOCE impairment has also been observed in astrocytes [168,169], microglia [169] and lymphoblasts from FAD patients [149], strongly suggesting a putative involvement of PSENs-related SOCE alterations in immune dysregulation occurring in $\mathrm{AD}[170]$.

\subsection{Huntington's Disease (HD)}

Huntington's disease (HD) is a progressive neurodegenerative disorder caused by a polyglutamine expansion in the huntingtin (HTT) protein, thus resulting in striatal degeneration through transcriptional dysregulation of a number of genes, including those regulating $\mathrm{Ca}^{2+}$ signaling as demonstrated both in experimental models and in patients [171-173]. At variance with $\mathrm{AD}, \mathrm{SOCE}$ is elevated in HD [172-175]. In both in vitro and in vivo models, SOCE pathway is indirectly and abnormally activated by mutant HTT (mHTT) in striatal $\gamma$-aminobutyric acid (GABA)ergic medium spiny neurons (MSNs) before symptoms onset, thus highlighting the role of this $\mathrm{Ca}^{2+}$ current in disease progression $[101,176]$. In fact, synaptic loss in MSNs was ascribed to SOCE elevation due to increased expression of STIM2, while STIM1 did not appear to be involved [174]. By contrast, in human or mouse neuroblastoma cells and in primary cultures of mouse MSNs, expression of the 
N-terminal fragment of mHTT results in increased SOCE through STIM1 and both TRPC and Orai1 [177,178].

Accumulating evidence suggests crosstalk between STIMs and NMDARs that may contribute to dendritic spines pathology in HD [94,95]. Indeed, NMDAR activation triggers $\mathrm{Ca}^{2+}$ release from ER stores, STIM1 aggregation and SOCE stimulation in diverse experimental contexts $[95,179]$. Although there is evidence that compounds that stabilize abnormal SOCE may prevent dendritic spine loss in HD, further work is needed to clarify whether therapeutic strategies specifically acting on SOCE components, including STIMs, deserve further scrutiny to reverse $\mathrm{Ca}^{2+}$ signalling dysregulation in HD [176].

\subsection{Parkinson's Disease (PD)}

Although the exact mechanisms involved in the pathogenesis of sporadic and familial Parkinson's disease (PD) are still unclear, the dysregulation of ER $\mathrm{Ca}^{2+}$ homeostasis is believed to be crucially involved in the selective loss of dopaminergic neurons of the substantia nigra pars compacta $[180,181]$. Rhythmic activity of dopaminergic neurons is typically dependent on L-type $\mathrm{Ca}_{\mathrm{V}} 1.3$ channels, and pharmacological inhibition of these currents restores $\mathrm{Ca}^{2+}$-independent 'juvenile' pacemaking activity and protects dopaminergic neurons in animal models of the disease [182].

A recent work has demonstrated that neurotoxins (i.e., 1-methyl-4-phenylpyridinium ion, $\mathrm{MPP}^{+}$) that mimic PD lead to degeneration of dopaminergic neurons by increasing $\mathrm{Ca}^{2+}$ influx through $\mathrm{Ca}_{\mathrm{V}} 1.3$ channel, by reducing TRPC1 expression, while inhibiting stimulation-dependent STIM1-Cav1.3 interaction [183]. Thus, TRPC1 suppresses Cav1.3 activity by providing a STIM1-based scaffold, which is crucial for proper firing and survival of dopaminergic neurons [183,184].

In PC12 cells treated with $\mathrm{MMP}^{+}$, SOCE blockade and STIM1 depletion reduce oxidative stress, prevent mitochondrial dysfunction and increase cell viability, supporting the hypothesis that SOCC through STIM1 underlies toxicity in this model [185]. In line with these findings is the recent evidence that Sigma 1 Receptors ( $\sigma 1 R s)$ are involved in the inhibition of TRPC1-mediated $\mathrm{Ca}^{2+}$ entry (by inhibiting STIM1 binding with TRPC1) in dopaminergic cells, whereby downregulation of $\sigma 1 \mathrm{Rs}$ expression or inhibition of $\sigma 1 \mathrm{R}$ activity substantially prevented $\mathrm{MPP}^{+}$-induced cell death by preserving $\mathrm{Ca}^{2+}$ homeostasis, mitochondrial and ER function, and inhibiting apoptosis [186]. In particular, store depletion, especially in the presence of external $\mathrm{Ca}^{2+}$, causes the dissociation of $\sigma 1 \mathrm{R}-\mathrm{STIM} 1$ complexes while facilitating STIM1-TRPC1-Orai1 interactions, which could also play a critical role in neuronal demise [186]. Nevertheless, the aforementioned data are in contrast with the observation that exposure to $\mathrm{MPP}^{+}$decreases TRPC1 expression, its interaction with STIM1 and $\mathrm{Ca}^{2+}$ entry in SH-SY5Y cells [187], underscoring the need of additional experiments to clarify the role of STIM1 and its partners in PD pathogenesis.

\subsection{Amyotrophic Lateral Sclerosis (ALS)}

Amyotrophic lateral sclerosis (ALS) is a devastating and fatal neurodegenerative disease characterized by a progressive loss of both upper and lower motor neurons. Molecularly, the disease has a complex pathogenesis including the deregulation of multiple intrinsic pathways and dysfunctional $\mathrm{Ca}^{2+}$ homeostasis [188]. In motor neurons, a tight physical coupling between STIM1 and the main lysosomal $\mathrm{Ca}^{2+}$ channel TRPML1 has been demonstrated, possibly to regulate lysosomal $\mathrm{Ca}^{2+}$ release, autophagy defects and cell survival in $\beta$-methylamino-L-alanine (L-BMAA)-treated motor neurons [68]. However, the fate of ALS motor neurons is significantly influenced also by the neighboring glial cells. Accordingly, astrocytes derived from a superoxide dismutase (SOD) 1 mutant mouse model of ALS or from brain tissue of ALS patients directly induce motor neuron loss in vitro. Interestingly, the ER calcium sensor STIM1 underlies the abnormal SOCE in SOD1 1 G93A astrocytes causing ER $\mathrm{Ca}^{2+}$ overload [189]. Furthermore, STIM1 accumulates in muscle fibers of ALS patients and in SOD1 ${ }^{\text {G93A }}$ transgenic mice [190]. While STIM1 co-localizes with SERCA1 and RyR1 in normal muscle fibers, it is associated only with RyR1 in partially 
atrophic fibers [190]. Interestingly, this is paralleled by a prominent increase in the autophagy marker LC3-II and p62, thus showing the occurrence of a dysfunctional autophagy also in ALS muscle fibers [190].

\section{Conclusions}

SOCE elicits specific cytosolic $\mathrm{Ca}^{2+}$ signals that are used by both excitable and nonexcitable cells for regulating critical physiological processes. The ER $\mathrm{Ca}^{2+}$ sensor STIM1 is responsible for SOCE machinery orchestration mainly through the interaction with Orai1 channel. However, several other STIM1 targets located in different cell compartments may serve to handle intracellular calcium concentration including plasmalemmal and intracellular channels (e.g., TRPC1, L-type voltage-dependent $\mathrm{Ca}^{2+}$ channels and TRPML1), and pumps (e.g., PMCA and SERCAs). Of note, the interaction between STIM1 and each of these ionic targets allows the regulation of both cytosolic and organellar $\mathrm{Ca}^{2+}$ homeostasis. Moreover, through the modulation of STIM1 activity and interaction, many adaptors indirectly intervene in intracellular calcium homeostasis regulation.

Several lines of experimental evidence clearly demonstrate that $\mathrm{Ca}^{2+}$ homeostasis and, most notably, STIM1 targets may be dysregulated in both acute and chronic neurodegenerative diseases. In fact, dysfunction of SOCE may contribute to the progression of several neurodegenerative diseases. For instance, SOCE activation appears to be neuroprotective in $\mathrm{PD}$ and $\mathrm{AD}$, while during HD progression, neuroprotection could be achieved by reducing SOCE. With stroke injury being a multifactorial pathology dependent on the dysfunctional activity of several cell types, the role of SOCE in this neurological disease remains controversial. Therefore, dissection of the molecular components sustaining SOCE should be performed at the level of each specific cell type in order to identify the exact role played by each of them. This is true especially at the level of central nervous system (CNS) cells, where SOCE plays a dualistic role in the different forms of neurodegeneration. On the other hand, STIM1 interacts with other proteins not canonically involved in SOCE and this interaction may be altered during the neurodegenerative process. For instance, dysfunction in STIM1/TRPML1 interaction participates in ALS and stroke pathogenesis through organellar ionic dysfunction. This should be carefully taken into account since each element able to interact with STIM1 should be considered as a putative target for the development of new pharmacological entities.

Collectively, considering the relevance of $\mathrm{Ca}^{2+}$ dyshomeostasis in neurodegeneration, the validation of new drugs toward STIM1 targets may result in successful treatment strategies for $\mathrm{AD}, \mathrm{PD}, \mathrm{HD}$, ALS and stroke.

Author Contributions: Writing-Original Draft Preparation, A.S., V.T. and D.A.; Image Curation, V.T.; Writing-Review and Editing, A.S., D.A., D.L.R., C.F. and A.V.; Funding Acquisition, A.S. and D.A. All authors have read and agreed to the published version of the manuscript.

Funding: This work was supported by Progetto Speciale di Ateneo CA.04_CDA_n_103 27.03.2019, Progetto di Ateneo Linea A CdA_54_2020_FRA to A. Secondo and by the Italian Ministry of Education, University of Research (PRIN2015-Prot. 2015KRYSJN to Agnese Secondo and Diana Amantea).

Conflicts of Interest: The authors declare no competing interest.

\section{References}

1. Csutora, P.; Peter, K.; Kilic, H.; Park, K.M.; Zarayskiy, V.; Gwozdz, T.; Bolotina, V.M. Novel role for STIM1 as a trigger for calcium influx factor production. J. Biol. Chem. 2008, 283, 14524-14531. [CrossRef] [PubMed]

2. Roos, J.; DiGregorio, P.J.; Yeromin, A.V.; Ohlsen, K.; Lioudyno, M.; Zhang, S.; Safrina, O.; Kozak, J.A.; Wagner, S.L.; Cahalan, M.D.; et al. STIM1, an essential and conserved component of store-operated $\mathrm{Ca}^{2+}$ channel function. J. Cell Biol. 2005, 169, 435-445. [CrossRef]

3. Stathopulos, P.B.; Li, G.Y.; Plevin, M.J.; Ames, J.B.; Ikura, M. Stored Ca ${ }^{2+}$ depletion-induced oligomerization of stromal interaction molecule 1 (STIM1) via the EF-SAM region: An initiation mechanism for capacitive $\mathrm{Ca}^{2+}$ entry. J. Biol. Chem. 2006, 281, 35855-35862. [CrossRef] [PubMed]

4. Darbellay, B.; Arnaudeau, S.; Bader, C.R.; Konig, S.; Bernheim, L. STIM1L is a new actin-binding splice variant involved in fast repetitive $\mathrm{Ca}^{2+}$ release. J. Cell Biol. 2011, 194, 335-346. [CrossRef] 
5. Dyrda, A.; Koenig, S.; Frieden, M. STIM1 long and STIM1 gate differently TRPC1 during store-operated calcium entry. Cell Calcium 2020, 86, 102134. [CrossRef] [PubMed]

6. Ramesh, G.; Jarzembowski, L.; Schwarz, Y.; Poth, V.; Konrad, M.; Knapp, M.L.; Schwär, G.; Lauer, A.A.; Grimm, M.O.W.; Alansary, D.; et al. A short isoform of STIM1 confers frequency-dependent synaptic enhancement. Cell Rep. 2021, 34, 108844. [CrossRef] [PubMed]

7. Brandman, O.; Liou, J.; Park, W.S.; Meyer, T. STIM2 is a feedback regulator that stabilizes basal cytosolic and endoplasmic reticulum $\mathrm{Ca}^{2+}$ levels. Cell 2007, 131, 1327-1339. [CrossRef] [PubMed]

8. Son, G.Y.; Subedi, K.P.; Ong, H.L.; Noyer, L.; Saadi, H.; Zheng, C.; Bhardwaj, R.; Feske, S.; Ambudkar, I.S. STIM2 targets Orai1/STIM1 to the AKAP79 signaling complex and confers coupling of $\mathrm{Ca}^{2+}$ entry with NFAT1 activation. Proc. Natl. Acad. Sci. USA 2020, 117, 16638-16648. [CrossRef]

9. Putney, J.W., Jr. A model for receptor-regulated calcium entry. Cell Calcium 1986, 7, 1-12. [CrossRef]

10. Cahalan, M.D.; Lewis, R.S. Functional roles of ion channels in lymphocytes. Semin. Immunol. 1990, 2, 107-117.

11. Hoth, M.; Penner, R. Depletion of intracellular calcium stores activates a calcium current in mast cells. Nature 1992, 355, 353-356. [CrossRef]

12. Hoth, M.; Penner, R. Calcium release-activated calcium current in rat mast cells. J. Physiol. 1993, 465, 359-386. [CrossRef] [PubMed]

13. Parekh, B.; Fleig, A.; Penner, R. The store-operated calcium current ICRAC: Nonlinear activation by InsP3 and dissociation from calcium release. Cell 1997, 89, 973-980. [CrossRef]

14. Penner, R.; Matthews, G.; Neher, E. Regulation of calcium influx by second messengers in rat mast cells. Nature 1988, 334, 499-504. [CrossRef] [PubMed]

15. Matthews, G.; Neher, E.; Penner, R. Second messenger-activated calcium influx in rat peritoneal mast cells. J. Physiol. 1989, 418, 105-130. [CrossRef] [PubMed]

16. Lewis, R.S.; Cahalan, M.D. Mitogen-induced oscillations of cytosolic $\mathrm{Ca}^{2+}$ and transmembrane $\mathrm{Ca}^{2+}$ current in human leukemic $\mathrm{T}$ cells. Cell Regul. 1989, 1, 99-112. [CrossRef]

17. Parekh, A.B.; Penner, R. Store depletion and calcium influx. Physiol. Rev. 1997, 77, 901-930. [CrossRef]

18. Zweifach, A.; Lewis, R.S. Mitogen-regulated $\mathrm{Ca}^{2+}$ current of $\mathrm{T}$ lymphocytes is activated by depletion of intracellular $\mathrm{Ca}^{2+}$ stores. Proc. Natl. Acad. Sci. USA 1993, 90, 6295-6299. [CrossRef] [PubMed]

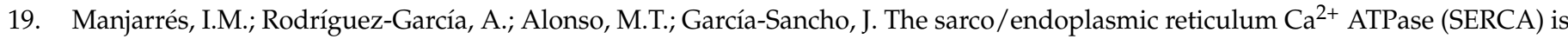
the third element in capacitative calcium entry. Cell Calcium 2010, 47, 412-418. [CrossRef]

20. Zhou, Y.; Nwokonko, R.M.; Cai, X.; Loktionova, N.A.; Abdulqadir, R.; Xin, P.; Niemeyer, B.A.; Wang, Y.; Trebak, M.; Gill, D.L. Cross-linking of Orai1 channels by STIM proteins. Proc. Natl. Acad. Sci. USA 2018, 115, E3398-E3407. [CrossRef] [PubMed]

21. Mercer, J.C.; Dehaven, W.I.; Smyth, J.T.; Wedel, B.; Boyles, R.R.; Bird, G.S.; Putney, J.W., Jr. Large store-operated calcium selective currents due to co-expression of Orai1 or Orai2 with the intracellular calcium sensor, Stim1. J. Biol. Chem. 2006, 281, 24979-24990. [CrossRef]

22. Fukushima, M.; Tomita, T.; Janoshazi, A.; Putney, J.W. Alternative translation initiation gives rise to two isoforms of Orai1 with distinct plasma membrane mobilities. J. Cell Sci. 2012, 125, 4354-4361. [CrossRef] [PubMed]

23. Feske, S. CRAC channels and disease-From human CRAC channelopathies and animal models to novel drugs. Cell Calcium 2019, 80, 112-116. [CrossRef]

24. McNally, B.A.; Somasundaram, A.; Yamashita, M.; Prakriya, M. Gated regulation of CRAC channel ion selectivity by STIM1. Nature 2012, 482, 241-245. [CrossRef] [PubMed]

25. Thompson, J.L.; Shuttleworth, T.J. Molecular basis of activation of the arachidonate-regulated Ca ${ }^{2+}(\mathrm{ARC}) \mathrm{channel}^{2}$ a storeindependent Orai channel, by plasma membrane STIM1. J. Physiol. 2013, 591, 3507-3523. [CrossRef] [PubMed]

26. Zhang, X.; Zhang, W.; Gonzalez-Cobos, J.C.; Jardin, I.; Romanin, C.; Matrougui, K.; Trebak, M. Complex role of STIM1 in the activation of store-independent Orai1/3 channels. J. Gen. Physiol. 2014, 143, 345-359. [CrossRef] [PubMed]

27. Desai, P.N.; Zhang, X.; Wu, S.; Janoshazi, A.; Bolimuntha, S.; Putney, J.W.; Trebak, M. Multiple types of calcium channels arising from alternative translation initiation of the Orai1 message. Sci. Signal. 2015, 8, ra74. [CrossRef] [PubMed]

28. Zitt, C.; Zobel, A.; Obukhov, A.G.; Harteneck, C.; Kalkbrenner, F.; Luckhoff, A.; Schultz, G. Cloning and functional expression of a human $\mathrm{Ca}^{2+}$-permeable cation channel activated by calcium store depletion. Neuron 1996, 16, 1189-1196. [CrossRef]

29. Zhu, X.; Jiang, M.; Peyton, M.; Boulay, G.; Hurst, R.; Stefani, E.; Birnbaumer, L. trp, a novel mammalian gene family essential for agonist-activated capacitative $\mathrm{Ca}^{2+}$ entry. Cell 1996, 85, 661-671. [CrossRef]

30. Liu, X.; Wang, W.; Singh, B.B.; Lockwich, T.; Jadlowiec, J.; O'Connell, B.; Wellner, R.; Zhu, M.X.; Ambudkar, I.S. Trp1, a candidate protein for the store-operated $\mathrm{Ca}^{2+}$ influx mechanism in salivary gland cells. J. Biol. Chem. 2000, 275, 3403-3411. [CrossRef]

31. Brough, G.H.; Wu, S.; Cioffi, D.; Moore, T.M.; Li, M.; Dean, N.; Stevens, T. Contribution of endogenously expressed Trp1 to a $\mathrm{Ca}^{2+}$-selective, store-operated $\mathrm{Ca}^{2+}$ entry pathway. FASEB J. 2001, 15, 1727-1738. [CrossRef] [PubMed]

32. Lopez, J.J.; Jardin, I.; Sanchez-Collado, J.; Salido, G.M.; Smani, T.; Rosado, J.A. TRPC Channels in the SOCE Scenario. Cells 2020, 9 , 126. [CrossRef] [PubMed]

33. Kim, M.S.; Zeng, W.; Yuan, J.P.; Shin, D.M.; Worley, P.F.; Muallem, S. Native Store-operated Ca ${ }^{2+}$ Influx Requires the Channel Function of Orai1 and TRPC1. J. Biol. Chem. 2009, 284, 9733-9741. [CrossRef] [PubMed] 
34. Ong, H.L.; Cheng, K.T.; Liu, X.; Bandyopadhyay, B.C.; Paria, B.C.; Soboloff, J.; Pani, B.; Gwack, Y.; Srikanth, S.; Singh, B.B.; et al. Dynamic assembly of TRPC1-STIM1-Orai1 ternary complex is involved in store-operated calcium influx. Evidence for similarities in store-operated and calcium release-activated calcium channel components. J. Biol. Chem. 2007, 282, 9105-9116. [CrossRef] [PubMed]

35. Jardin, I.; Lopez, J.J.; Salido, G.M.; Rosado, J.A. Orai1 mediates the interaction between STIM1 and hTRPC1 and regulates the mode of activation of hTRPC1-forming $\mathrm{Ca}^{2+}$ channels. J. Biol. Chem. 2008, 283, 25296-25304. [CrossRef] [PubMed]

36. Albert, A.P.; Large, W.A. A Ca ${ }^{2+}$-permeable non-selective cation channel activated by depletion of internal $\mathrm{Ca}^{2+}$ stores in single rabbit portal vein myocytes. J. Physiol. 2002, 538, 717-728. [CrossRef] [PubMed]

37. Cheng, K.T.; Liu, X.; Ong, H.L.; Swaim, W.; Ambudkar, I.S. Local Ca ${ }^{2+}$ entry via Orai1 regulates plasma membrane recruitment of TRPC1 and controls cytosolic $\mathrm{Ca}^{2+}$ signals required for specific cell functions. PLoS Biol. 2011, 9, e1001025. [CrossRef]

38. Moreno, C.; Vaca, L. SOC and now also SIC: Store-operated and store-inhibited channels. IUBMB Life 2011, 63, 856-863. [CrossRef]

39. Zarayskiy, V.; Monje, F.; Peter, K.; Csutora, P.; Khodorov, B.I.; Bolotina, V.M. Store-operated Orai1 and IP3 receptor-operated TRPC1 channel. Channels 2007, 1, 246-252. [CrossRef]

40. Ong, H.L.; Ambudkar, I.S. The dynamic complexity of the TRPC1 channelosome. Channels 2011, 5, 424-431. [CrossRef]

41. Wang, H.; Cheng, X.; Tian, J.; Xiao, Y.; Tian, T.; Xu, F.; Hong, X.; Zhu, M.X. TRPC channels: Structure, function, regulation and recent advances in small molecular probes. Pharmacol. Ther. 2020, 209, 107497. [CrossRef] [PubMed]

42. Moore, T.M.; Brough, G.H.; Babal, P.; Kelly, J.J.; Li, M.; Stevens, T. Store-operated calcium entry promotes shape change in pulmonary endothelial cells expressing Trp1. Am. J. Physiol. 1998, 275, L574-L582. [CrossRef] [PubMed]

43. Hu, Q.; Ahmad, A.A.; Seidel, T.; Hunter, C.; Streiff, M.; Nikolova, L.; Spitzer, K.W.; Sachse, F.B. Location and function of transient receptor potential canonical channel 1 in ventricular myocytes. J. Mol. Cell. Cardiol. 2020, 139, 113-123. [CrossRef] [PubMed]

44. Elzamzamy, O.M.; Penner, R.; Hazlehurst, L.A. The Role of TRPC1 in Modulating Cancer Progression. Cells 2020, 9, 388. [CrossRef] [PubMed]

45. Srikanth, S.; Gwack, Y. Orai1-NFAT signalling pathway triggered by T cell receptor stimulation. Mol. Cells 2013, 35, 182-194. [CrossRef] [PubMed]

46. Ritchie, M.F.; Samakai, E.; Soboloff, J. STIM1 is required for attenuation of PMCA-mediated Ca ${ }^{2+}$ clearance during T-cell activation. EMBO J. 2012, 31, 1123-1133. [CrossRef]

47. Peinelt, C.; Vig, M.; Koomoa, D.L.; Beck, A.; Nadler, M.J.; Koblan-Huberson, M.; Lis, A.; Fleig, A.; Penner, R.; Kinet, J.P. Amplification of CRAC current by STIM1 and CRACM1 (Orai1). Nat. Cell Biol. 2006, 8, 771-773. [CrossRef]

48. Soboloff, J.; Spassova, M.A.; Tang, X.D.; Hewavitharana, T.; Xu, W.; Gill, D.L. Orai1 and STIM reconstitute store-operated calcium channel function. J. Biol. Chem. 2006, 281, 20661-20665. [CrossRef]

49. Worley, P.F.; Zeng, W.; Huang, G.N.; Yuan, J.P.; Kim, J.Y.; Lee, M.G.; Muallem, S. TRPC channels as STIM1-regulated store-operated channels. Cell Calcium 2007, 42, 205-211. [CrossRef]

50. Yuan, J.P.; Zeng, W.; Huang, G.N.; Worley, P.F.; Muallem, S. STIM1 heteromultimerizes TRPC channels to determine their function as store-operated channels. Nat. Cell Biol. 2007, 9, 636-645. [CrossRef]

51. Park, C.Y.; Shcheglovitov, A.; Dolmetsch, R. The CRAC channel activator STIM1 binds and inhibits L-type voltage-gated calcium channels. Science 2010, 330, 101-105. [CrossRef] [PubMed]

52. Wang, Y.; Deng, X.; Mancarella, S.; Hendron, E.; Eguchi, S.; Soboloff, J.; Tang, X.D.; Gill, D.L. The calcium store sensor, STIM1, reciprocally controls Orai and CaV1.2 channels. Science 2010, 330, 105-109. [CrossRef]

53. Go, C.K.; Hooper, R.; Aronson, M.R.; Schultz, B.; Cangoz, T.; Nemani, N.; Zhang, Y.; Madesh, M.; Soboloff, J. The Ca ${ }^{2+}$ export pump PMCA clears near-membrane $\mathrm{Ca}^{2+}$ to facilitate store-operated $\mathrm{Ca}^{2+}$ entry and NFAT activation. Sci. Signal 2019, 12, eaaw2627. [CrossRef] [PubMed]

54. Gusarova, G.A.; Trejo, H.E.; Dada, L.A.; Briva, A.; Welch, L.C.; Hamanaka, R.B.; Mutlu, G.M.; Chandel, N.S.; Prakriya, M.; Sznajder, J.I. Hypoxia leads to Na,K-ATPase downregulation via $\mathrm{Ca}^{2+}$ release-activated $\mathrm{Ca}^{2+}$ channels and AMPK activation. Mol. Cell. Biol. 2011, 31, 3546-3556. [CrossRef]

55. Liao, Y.; Erxleben, C.; Abramowitz, J.; Flockerzi, V.; Zhu, M.X.; Armstrong, D.L.; Birnbaumer, L. Functional interactions among Orai1, TRPCs, and STIM1 suggest a STIM-regulated heteromeric Orai/TRPC model for SOCE/Icrac channels. Proc. Natl. Acad. Sci. USA 2008, 105, 2895-2900. [CrossRef] [PubMed]

56. Sampieri, A.; Zepeda, A.; Asanov, A.; Vaca, L. Visualizing the store-operated channel complex assembly in real time: Identification of SERCA2 as a new member. Cell Calcium 2009, 45, 439-446. [CrossRef] [PubMed]

57. López, J.J.; Jardín, I.; Bobe, R.; Pariente, J.A.; Enouf, J.; Salido, G.M.; Rosado, J.A. STIM1 regulates acidic Ca ${ }^{2+}$ store refilling by interaction with SERCA3 in human platelets. Biochem. Pharmacol. 2008, 75, 2157-2164. [CrossRef] [PubMed]

58. Schrader, M.; Godinho, L.F.; Costello, J.L.; Islinger, M. The different facets of organelle interplay-An overview of organelle interactions. Front. Cell Dev. Biol. 2015, 3, 56. [CrossRef] [PubMed]

59. Han, Y.; Li, M.; Qiu, F.; Zhang, M.; Zhang, Y.H. Cell-permeable organic fluorescent probes for live-cell long-term super-resolution imaging reveal lysosome-mitochondrion interactions. Nat. Commun. 2017, 8, 1307. [CrossRef] [PubMed]

60. De Duve, C. The lysosome turns fifty. Nat. Cell Biol. 2005, 7, 847-849. [CrossRef]

61. Yu, L.; Chen, Y.; Tooze, S.A. Autophagy pathway: Cellular and molecular mechanisms. Autophagy 2018, 14, 207-215. [CrossRef] [PubMed] 
62. Patel, S.; Docampo, R. Acidic calcium stores open for business: Expanding the potential for intracellular Ca ${ }^{2+}$ signaling. Trends Cell Biol. 2010, 20, 277-286. [CrossRef] [PubMed]

63. Morgan, A.J.; Platt, F.M.; Lloyd-Evans, E.; Galione, A. Molecular mechanisms of endolysosomal $\mathrm{Ca}^{2+}$ signalling in health and disease. Biochem. J. 2011, 439, 349-374. [CrossRef] [PubMed]

64. Calcraft, P.J.; Ruas, M.; Pan, Z.; Cheng, X.; Arredouani, A.; Hao, X.; Tang, J.; Rietdorf, K.; Teboul, L.; Chuang, K.T.; et al. NAADP mobilizes calcium from acidic organelles through two-pore channels. Nature 2009, 459, 596-600. [CrossRef]

65. Dong, X.P.; Shen, D.; Wang, X.; Dawson, T.; Li, X.; Zhang, Q.; Cheng, X.; Zhang, Y.; Weisman, L.S.; Delling, M.; et al. PI(3,5)P(2) controls membrane trafficking by direct activation of mucolipin $\mathrm{Ca}^{2+}$ release channels in the endolysosome. Nat. Commun. 2010, 1, 38. [CrossRef]

66. Morgan, A.J.; Davis, L.C.; Wagner, S.K.; Lewis, A.M.; Parrington, J.; Churchill, G.C.; Galione, A. Bidirectional Ca ${ }^{2+}$ signaling occurs between the endoplasmic reticulum and acidic organelles. J. Cell Biol. 2013, 200, 789-805. [CrossRef]

67. Kilpatrick, B.S.; Magalhaes, J.; Beavan, M.S.; McNeill, A.; Gegg, M.E.; Cleeter, M.W.; Bloor-Young, D.; Churchill, G.C.; Duchen, M.R.; Schapira, A.H.; et al. Endoplasmic reticulum and lysosomal $\mathrm{Ca}^{2+}$ stores are remodelled in GBA1-linked Parkinson disease patient fibroblasts. Cell Calcium 2016, 59, 12-20. [CrossRef]

68. Tedeschi, V.; Petrozziello, T.; Sisalli, M.J.; Boscia, F.; Canzoniero, L.M.T.; Secondo, A. The activation of Mucolipin TRP channel 1 (TRPML1) protects motor neurons from L-BMAA neurotoxicity by promoting autophagic clearance. Sci. Rep. $2019,9,10743$. [CrossRef]

69. Tedeschi, V.; Sisalli, M.J.; Petrozziello, T.; Canzoniero, L.M.T.; Secondo, A. Lysosomal calcium is modulated by STIM1/TRPML1 interaction which participates to neuronal survival during ischemic preconditioning. FASEB J. 2021, 35, e21277. [CrossRef]

70. Saitoh, N.; Oritani, K.; Saito, K.; Yokota, T.; Ichii, M.; Sudo, T.; Fujita, N.; Nakajima, K.; Okada, M.; Kanakura, Y. Identification of functional domains and novel binding partners of STIM proteins. J. Cell. Biochem. 2011, 112, 147-156. [CrossRef]

71. Krapivinsky, G.; Krapivinsky, L.; Stotz, S.C.; Manasian, Y.; Clapham, D.E. POST, partner of stromal interaction molecule 1 (STIM1), targets STIM1 to multiple transporters. Proc. Natl. Acad. Sci. USA 2011, 108, 19234-19239. [CrossRef] [PubMed]

72. Kim, T.D.; Jung, H.R.; Seo, S.H.; Oh, S.C.; Ban, Y.; Tan, X.; Kim, J.M.; Lee, S.H.; Koh, D.S.; Jung, H.; et al. MicroRNA-150 modulates intracellular $\mathrm{Ca}^{2+}$ levels in naïve $\mathrm{CD}^{8+} \mathrm{T}$ cells by targeting TMEM20. Sci. Rep. 2017, 7, 2623. [CrossRef]

73. Srikanth, S.; Gwack, Y. Orai1, STIM1, and their associating partners. J. Physiol. 2012, 590, 4169-4177. [CrossRef] [PubMed]

74. Sharma, S.; Quintana, A.; Findlay, G.M.; Mettlen, M.; Baust, B.; Jain, M.; Nilsson, R.; Rao, A.; Hogan, P.G. An siRNA screen for NFAT activation identifies septins as coordinators of store-operated $\mathrm{Ca}^{2+}$ entry. Nature 2013, 499, 238-242. [CrossRef]

75. Miao, Y.; Miner, C.; Zhang, L.; Hanson, P.I.; Dani, A.; Vig, M. An essential and NSF independent role for $\alpha$-SNAP in store-operated calcium entry. eLife 2013, 2, e00802. [CrossRef] [PubMed]

76. Jing, J.; He, L.; Sun, A.; Quintana, A.; Ding, Y.; Ma, G.; Tan, P.; Liang, X.; Zheng, X.; Chen, L.; et al. Proteomic mapping of ER-PM junctions identifies STIMATE as a regulator of $\mathrm{Ca}^{2+}$ influx. Nat. Cell Biol. 2015, 17, 1339-1347. [CrossRef]

77. Hooper, R.; Soboloff, J. STIMATE reveals a STIM1 transitional state. Nat. Cell Biol. 2015, 17, 1232-1234. [CrossRef]

78. López, J.J.; Albarrán, L.; Gómez, L.J.; Smani, T.; Salido, G.M.; Rosado, J.A. Molecular modulators of store-operated calcium entry. Biochim. Biophys. Acta 2016, 1863, 2037-2043. [CrossRef]

79. Serwach, K.; Gruszczynska-Biegala, J. Target Molecules of STIM Proteins in the Central Nervous System. Front. Mol. Neurosci. 2020, 13, 617422. [CrossRef]

80. Palty, R.; Raveh, A.; Kaminsky, I.; Meller, R.; Reuveny, E. SARAF inactivates the store operated calcium entry machinery to prevent excess calcium refilling. Cell 2012, 49, 425-438. [CrossRef]

81. Albarrán, L.; López, J.J.; Gómez, L.J.; Salido, G.M.; Rosado, J.A. SARAF modulates TRPC1, but not TRPC6, channel function in a STIM1-independent manner. Biochem. J. 2016, 473, 3581-3595. [CrossRef] [PubMed]

82. Albarrán, L.; López, J.J.; Ben, A.N.; Martin-Cano, F.E.; Berna-Erro, A.; Smani, T.; Salido, G.M.; Rosado, J.A. Dynamic interaction of SARAF with STIM1 and Orai1 to modulate store-operated calcium entry. Sci. Rep. 2016, 6, 24452. [CrossRef] [PubMed]

83. Woodward, O.M.; Li, Y.; Yu, S.; Greenwell, P.; Wodarczyk, C.; Boletta, A.; Guggino, W.B.; Qian, F. Identification of a polycystin-1 cleavage product, P100, that regulates store operated Ca entry through interactions with STIM1. PLoS ONE 2010, 5, e12305. [CrossRef] [PubMed]

84. Prins, D.; Groenendyk, J.; Touret, N.; Michalak, M. Modulation of STIM1 and capacitative Ca ${ }^{2+}$ entry by the endoplasmic reticulum luminal oxidoreductase ERp57. EMBO Rep. 2011, 12, 1182-1188. [CrossRef]

85. Di Buduo, C.A.; Abbonante, V.; Marty, C.; Moccia, F.; Rumi, E.; Pietra, D.; Soprano, P.M.; Lim, D.; Cattaneo, D.; Iurlo, A.; et al. Defective interaction of mutant calreticulin and SOCE in megakaryocytes from patients with myeloproliferative neoplasms. Blood 2020, 135, 133-144. [CrossRef]

86. Zeiger, W.; Ito, D.; Swetlik, C.; Oh-hora, M.; Villereal, M.L.; Thinakaran, G. Stanniocalcin 2 is a negative modulator of storeoperated calcium entry. Mol. Cell. Biol. 2011, 31, 3710-3722. [CrossRef]

87. López, E.; Gómez-Gordo, L.; Cantonero, C.; Bermejo, N.; Pérez-Gómez, J.; Granados, M.P.; Salido, G.N.; Dionisio, G.A.R.; Liberal, P.C.R. Stanniocalcin 2 Regulates Non-capacitative $\mathrm{Ca}^{2+}$ Entry and Aggregation in Mouse Platelets. Front. Physiol. $2018,9,266$. [CrossRef]

88. Grigoriev, I.; Gouveia, S.M.; van der Vaart, B.; Demmers, J.; Smyth, J.T.; Honnappa, S.; Splinter, D.; Steinmetz, M.O.; Putney, J.W., Jr.; Hoogenraad, C.C.; et al. STIM1 is a MT-plus-end-tracking protein involved in remodeling of the ER. Curr. Biol. 2008, 18, 177-182. [CrossRef] 
89. Chang, C.L.; Chen, Y.J.; Quintanilla, C.G.; Hsieh, T.S.; Liou, J. EB1 binding restricts STIM1 translocation to ER-PM junctions and regulates store-operated $\mathrm{Ca}^{2+}$ entry. J. Cell Biol. 2018, 217, 2047-2058. [CrossRef]

90. Walsh, C.M.; Doherty, M.K.; Tepikin, A.V.; Burgoyne, R.D. Evidence for an interaction between Golli and STIM1 in store-operated calcium entry. Biochem. J. 2010, 430, 453-460. [CrossRef]

91. Reyes, S.D.; Campagnoni, A.T. Two separate domains in the golli myelin basic proteins are responsible for nuclear targeting and process extension in transfected cells. J. Neurosci. Res. 2002, 69, 587-596. [CrossRef] [PubMed]

92. Li, Y.; Song, J.; Liu, X.; Zhang, M.; An, J.; Sun, P.; Li, D.; Jin, T.; Wang, J. High expression of STIM1 in the early stages of diffuse axonal injury. Brain Res. 2013, 1495, 95-102. [CrossRef] [PubMed]

93. Hou, P.F.; Liu, Z.H.; Li, N.; Cheng, W.J.; Guo, S.W. Knockdown of STIM1 improves neuronal survival after traumatic neuronal injury through regulating mGluR1-dependent $\mathrm{Ca}^{2+}$ signaling in mouse cortical neurons. Cell. Mol. Neurobiol. 2015, 35, $283-292$. [CrossRef] [PubMed]

94. Gruszczynska-Biegala, J.; Strucinska, K.; Maciag, F.; Majewski, L.; Sladowska, M.; Kuznicki, J. STIM protein-NMDA2 receptor interaction decreases NMDA-dependent calcium levels in cortical neurons. Cells 2020, 9, 160. [CrossRef] [PubMed]

95. Dittmer, P.J.; Wild, A.R.; Dell'Acqua, M.L.; Sather, W.A. STIM1 Ca ${ }^{2+}$ sensor control of L-type Ca ${ }^{2+}$ channel-dependent dendritic spine structural plasticity and nuclear signaling. Cell Rep. 2017, 19, 321-334. [CrossRef]

96. Wegierski, T.; Kuznicki, J. Neuronal calcium signaling via store-operated channels in health and disease. Cell Calcium 2018, 74, 102-111. [CrossRef] [PubMed]

97. Serwach, K.; Gruszczynska-Biegala, J. STIM Proteins and Glutamate Receptors in Neurons: Role in Neuronal Physiology and Neurodegenerative Diseases. Int. J. Mol. Sci. 2019, 20, 2289. [CrossRef]

98. Lau, A.; Tymianski, M. Glutamate receptors, neurotoxicity and neurodegeneration. Pflug. Arch. 2010, 460, 525-542. [CrossRef]

99. Gonzalez, J.; Jurado-Coronel, J.C.; Ávila, M.F.; Sabogal, A.; Capani, F.; Barreto, G.E. NMDARs in neurological diseases: A potential therapeutic target. Int. J. Neurosci. 2015, 125, 315-327. [CrossRef]

100. Carvajal, F.J.; Mattison, H.A.; Cerpa, W. Role of NMDA Receptor-Mediated Glutamatergic Signaling in Chronic and Acute Neuropathologies. Neural Plast. 2016, 2016, 2701526. [CrossRef]

101. Pchitskaya, E.; Popugaeva, E.; Bezprozvanny, I. Calcium signaling and molecular mechanisms underlying neurodegenerative diseases. Cell Calcium 2018, 70, 87-94. [CrossRef] [PubMed]

102. Simpson, P.B.; Challiss, R.A.; Nahorski, S.R. Neuronal Ca ${ }^{2+}$ stores: Activation and function. Trends Neurosci. 1995, 18, $299-306$. [CrossRef]

103. Emptage, N.; Bliss, T.V.; Fine, A. Single synaptic events evoke NMDA receptor-mediated release of calcium from internal stores in hippocampal dendritic spines. Neuron 1999, 22, 115-124. [CrossRef]

104. Emptage, N.J.; Reid, C.A.; Fine, A. Calcium stores in hippocampal synaptic boutons mediate short-term plasticity, store-operated $\mathrm{Ca}^{2+}$ entry, and spontaneous transmitter release. Neuron 2001, 29, 197-208. [CrossRef]

105. Bogeski, I.; Niemeyer, B.A. Redox regulation of ion channels. Antioxid. Redox Signal. 2014, 21, 859-862. [CrossRef]

106. Nunes, P.; Demaurex, N. Redox regulation of store-operated Ca ${ }^{2+}$ entry. Antioxid. Redox Signal. 2014, 21, 915-932. [CrossRef] [PubMed]

107. Bhardwaj, R.; Hediger, M.A.; Demaurex, N. Redox modulation of STIM-ORAI signaling. Cell Calcium 2016, 60, 142-152. [CrossRef]

108. Niemeyer, B.A. The STIM-Orai Pathway: Regulation of STIM and Orai by Thiol Modifications. Adv. Exp. Med. Biol. 2017, 993, 99-116. [CrossRef]

109. Bogeski, I.; Kummerow, C.; Al-Ansary, D.; Schwarz, E.C.; Koehler, R.; Kozai, D.; Takahashi, N.; Peinelt, C.; Griesemer, D.; Bozem, M.; et al. Differential redox regulation of ORAI ion channels: A mechanism to tune cellular calcium signaling. Sci. Signal. 2010, 3, ra24. [CrossRef]

110. Hawkins, B.J.; Irrinki, K.M.; Mallilankaraman, K.; Lien, Y.C.; Wang, Y.; Bhanumathy, C.D.; Subbiah, R.; Ritchie, M.F.; Soboloff, J.; Baba, Y.; et al. S-glutathionylation activates STIM1 and alters mitochondrial homeostasis. J. Cell Biol. 2010, 190, 391-405. [CrossRef]

111. Gibhardt, C.S.; Cappello, S.; Bhardwaj, R.; Schober, R.; Kirsch, S.A.; Del Rio, Z.B.; Gahbauer, S.; Bochicchio, A.; Sumanska, M.; Ickes, C.; et al. Oxidative Stress-Induced STIM2 Cysteine Modifications Suppress Store-Operated Calcium Entry. Cell Rep. 2020, 33, 108292. [CrossRef] [PubMed]

112. Gui, L.; Zhu, J.; Lu, X.; Sims, S.M.; Lu, W.Y.; Stathopulos, P.B.; Feng, Q. S-Nitrosylation of STIM1 by Neuronal Nitric Oxide Synthase Inhibits Store-Operated $\mathrm{Ca}^{2+}$ Entry. J. Mol. Biol. 2018, 430, 1773-1785. [CrossRef]

113. Zhu, J.; Lu, X.; Feng, Q.; Stathopulos, P.B. A charge-sensing region in the stromal interaction molecule 1 luminal domain confers stabilization-mediated inhibition of SOCE in response to S-nitrosylation. J. Biol. Chem. 2018, 293, 8900-8911. [CrossRef] [PubMed]

114. Secondo, A.; Petrozziello, T.; Tedeschi, V.; Boscia, F.; Vinciguerra, A.; Ciccone, R.; Pannaccione, A.; Molinaro, P.; Pignataro, G.; Annunziato, L. ORAI1/STIM1 Interaction Intervenes in Stroke and in Neuroprotection Induced by Ischemic Preconditioning Through Store-Operated Calcium Entry. Stroke 2019, 50, 1240-1249. [CrossRef] [PubMed]

115. Sirabella, R.; Secondo, A.; Pannaccione, A.; Scorziello, A.; Valsecchi, V.; Adornetto, A.; Bilo, L.; Di Renzo, G.; Annunziato, L. Anoxia-induced NF-kappaB-dependent upregulation of NCX1 contributes to $\mathrm{Ca}^{2+}$ refilling into endoplasmic reticulum in cortical neurons. Stroke 2009, 40, 922-929. [CrossRef]

116. Parekh, A.B. Store-operated CRAC channels: Function in health and disease. Nat. Rev. Drug Discov. 2010, 9, 399-410. [CrossRef] 
117. Lang, F.; Pelzl, L.; Hauser, S.; Hermann, A.; Stournaras, C.; Schöls, L. To die or not to die SGK1-sensitive ORAI/STIM in cell survival. Cell Calcium 2018, 74, 29-34. [CrossRef]

118. Lehotský, J.; Racay, P.; Pavlíková, M.; Tatarková, Z.; Urban, P.; Chomová, M.; Kovalská, M.; Kaplán, P. Cross-talk of intracellular calcium stores in the response to neuronal ischemia and ischemic tolerance. Gen. Physiol. Biophys. 2009, 28, F104-F114.

119. Berna-Erro, A.; Braun, A.; Kraft, R.; Kleinschnitz, C.; Schuhmann, M.K.; Stegner, D.; Wultsch, T.; Eilers, J.; Meuth, S.G.; Stoll, G.; et al. STIM2 Regulates Capacitive $\mathrm{Ca}^{2+}$ Entry in Neurons and Plays a Key Role in Hypoxic Neuronal Cell Death. Sci. Signal. 2009, 2, ra67. [CrossRef]

120. Zhang, M.; Song, J.N.; Wu, Y.; Zhao, Y.L.; Pang, H.G.; Fu, Z.F.; Zhang, B.F.; Ma, X.D. Suppression of STIM1 in the early stage after global ischemia attenuates the injury of delayed neuronal death by inhibiting store-operated calcium entry-induced apoptosis in rats. Neuroreport 2014, 25, 507-513. [CrossRef]

121. Soboloff, J.; Spassova, M.A.; Hewavitharana, T.; He, L.P.; Xu, W.; Johnstone, L.S.; Dziadek, M.A.; Gill, D.L. STIM2 is an inhibitor of STIM1-mediated store-operated Ca ${ }^{2+}$ Entry. Curr. Biol. 2006, 16, 1465-1470. [CrossRef]

122. Vig, M.; Peinelt, C.; Beck, A.; Koomoa, D.L.; Rabah, D.; Koblan-Huberson, M.; Kraft, S.; Turner, H.; Fleig, A.; Penner, R.; et al CRACM1 is a plasma membrane protein essential for store-operated Ca ${ }^{2+}$ entry. Science 2006, 312, 1220-1223. [CrossRef] [PubMed]

123. La Russa, D.; Frisina, M.; Secondo, A.; Bagetta, G.; Amantea, D. Modulation of Cerebral Store-operated Calcium Entry-regulatory Factor (SARAF) and Peripheral Orai1 Following Focal Cerebral Ischemia and Preconditioning in Mice. Neuroscience 2020, 441, 8-21. [CrossRef] [PubMed]

124. Ohara, H.; Nabika, T. A nonsense mutation of Stim1 identified in stroke-prone spontaneously hypertensive rats decreased the store-operated calcium entry in astrocytes. Biochem. Biophys. Res. Commun. 2016, 476, 406-411. [CrossRef] [PubMed]

125. Goedert, M.; Spillantini, M.G. A century of Alzheimer's disease. Science 2006, 314, 777-781. [CrossRef]

126. Hardy, J.; Selkoe, D.J. The amyloid hypothesis of Alzheimer's disease: Progress and problems on the road to therapeutics. Science 2002, 297, 353-356. [CrossRef]

127. Panza, F.; Solfrizzi, V.; Imbimbo, B.P.; Logroscino, G. Amyloid-directed monoclonal antibodies for the treatment of Alzheimer's disease: The point of no return? Expert Opin. Biol. Ther. 2014, 14, 1465-1476. [CrossRef]

128. Godyń, J.; Jończyk, J.; Panek, D.; Malawska, B. Therapeutic strategies for Alzheimer's disease in clinical trials. Pharmacol. Rep. 2016, 68, 127-138. [CrossRef]

129. Schon, E.A.; Area-Gomez, E. Mitochondria-associated ER membranes in Alzheimer disease. Mol. Cell. Neurosci. 2013, 55, 26-36. [CrossRef]

130. Giacomello, M.; Barbiero, L.; Zatti, G.; Squitti, R.; Binetti, G.; Pozzan, T.; Fasolato, C.; Ghidoni, R.; Pizzo, P. Reduction of Ca ${ }^{2+}$ stores and capacitative $\mathrm{Ca}^{2+}$ entry is associated with the familial Alzheimer's disease presenilin-2 T122R mutation and anticipates the onset of dementia. Neurobiol. Dis. 2005, 18, 638-648. [CrossRef]

131. Ito, E.; Oka, K.; Etcheberrigaray, R.; Nelson, T.J.; McPhie, D.L.; Tofel-Grehl, B.; Gibson, G.E.; Alkon, D.L. Internal Ca ${ }^{2+}$ mobilization is altered in fibroblasts from patients with Alzheimer disease. Proc. Natl. Acad. Sci. USA 1994, 91, 534-538. [CrossRef] [PubMed]

132. Etcheberrigaray, R.; Hirashima, N.; Nee, L.; Prince, J.; Govoni, S.; Racchi, M.; Tanzi, R.E.; Alkon, D.L. Calcium responses in fibroblasts from asymptomatic members of Alzheimer's disease families. Neurobiol. Dis. 1998, 5, 37-45. [CrossRef] [PubMed]

133. Ureshino, R.P.; Erustes, A.G.; Bassani, T.B.; Wachilewski, P.; Guarache, G.C.; Nascimento, A.C.; Costa, A.J.; Smaili, S.S.; Pereira, G.J.D.S. The Interplay between $\mathrm{Ca}^{2+}$ Signaling Pathways and Neurodegeneration. Int. J. Mol. Sci. 2019, 20, 6004. [CrossRef] [PubMed]

134. Cheung, K.H.; Shineman, D.; Muller, M.; Cardenas, C.; Mei, L.; Yang, J.; Tomita, T.; Iwatsubo, T.; Lee, V.M.; Foskett, J.K. Mechanism of $\mathrm{Ca}^{2+}$ disruption in Alzheimer's disease by presenilin regulation of InsP3 receptor channel gating. Neuron 2008, 58, 871-883. [CrossRef]

135. Cheung, K.H.; Mei, L.; Mak, D.O.; Hayashi, I.; Iwatsubo, T.; Kang, D.E.; Foskett, J.K. Gain-of-function enhancement of IP3 receptor modal gating by familial Alzheimer's disease-linked presenilin mutants in human cells and mouse neurons. Sci. Signal. 2010, 3, ra22. [CrossRef] [PubMed]

136. Shilling, D.; Muller, M.; Takano, H.; Mak, D.O.; Abel, T.; Coulter, D.A.; Foskett, J.K. Suppression of InsP3 receptor-mediated $\mathrm{Ca}^{2+}$ signaling alleviates mutant presenilin-linked familial Alzheimer's disease pathogenesis. J. Neurosci. 2014, 34, 6910-6923. [CrossRef]

137. Mak, D.O.; Cheung, K.H.; Toglia, P.; Foskett, J.K.; Ullah, G. Analyzing and quantifying the gain-of-function enhancement of IP3 receptor gating by familial Alzheimer's disease-causing mutants in Presenilins. PLoS Comput. Biol. 2015, 11, e1004529. [CrossRef] [PubMed]

138. Rybalchenko, V.; Hwang, S.Y.; Rybalchenko, N.; Koulen, P. The cytosolic N-terminus of presenilin-1 potentiates mouse ryanodine receptor single channel activity. Int. J. Biochem. Cell Biol. 2008, 40, 84-97. [CrossRef] [PubMed]

139. Green, K.N.; Demuro, A.; Akbari, Y.; Hitt, B.D.; Smith, I.F.; Parker, I.; LaFerla, F.M. SERCA pump activity is physiologically regulated by presenilin and regulates amyloid beta production. J. Cell Biol. 2008, 181, 1107-1116. [CrossRef]

140. Greotti, E.; Capitanio, P.; Wong, A.; Pozzan, T.; Pizzo, P.; Pendin, D. Familial Alzheimer's disease-linked presenilin mutants and intracellular $\mathrm{Ca}^{2+}$ handling: A single-organelle, FRET-based analysis. Cell Calcium 2019, 79, 44-56. [CrossRef]

141. Tong, B.C.; Lee, C.S.; Cheng, W.H.; Lai, K.O.; Kevin Foskett, J.; Cheung, K.H. Familial Alzheimer's disease-associated presenilin 1 mutants promote gamma-secretase cleavage of STIM1 to impair store-operated $\mathrm{Ca}^{2+}$ entry. Sci. Signal. 2016, 9, ra89. [CrossRef] 
142. Zatti, G.; Ghidoni, R.; Barbiero, L.; Binetti, G.; Pozzan, T.; Fasolato, C.; Pizzo, P. The presenilin 2 M239I mutation associated with familial Alzheimer's disease reduces $\mathrm{Ca}^{2+}$ release from intracellular stores. Neurobiol. Dis. 2004, 15, 269-278. [CrossRef] [PubMed]

143. Zatti, G.; Burgo, A.; Giacomello, M.; Barbiero, L.; Ghidoni, R.; Sinigaglia, G.; Florean, C.; Bagnoli, S.; Binetti, G.; Sorbi, S.; et al. Presenilin mutations linked to familial Alzheimer's disease reduce endoplasmic reticulum and Golgi apparatus calcium levels. Cell Calcium 2006, 39, 539-550. [CrossRef] [PubMed]

144. Leissring, M.A.; Akbari, Y.; Fanger, C.M.; Cahalan, M.D.; Mattson, M.P.; LaFerla, F.M. Capacitative calcium entry deficits and elevated luminal calcium content in mutant presenilin-1 knockin mice. J. Cell Biol. 2000, 149, 793-798. [CrossRef] [PubMed]

145. Smith, I.F.; Boyle, J.P.; Vaughan, P.F.; Pearson, H.A.; Cowburn, R.F.; Peers, C.S. $\mathrm{Ca}^{2+}$ stores and capacitative Ca ${ }^{2+}$ entry in human neuroblastoma (SH-SY5Y) cells expressing a familial Alzheimer's disease presenilin-1 mutation. Brain Res. 2002, 949, 105-111. [CrossRef]

146. Yoo, A.S.; Cheng, I.; Chung, S.; Grenfell, T.Z.; Lee, H.; Pack-Chung, E.; Handler, M.; Shen, J.; Xia, W.; Tesco, G.; et al. Presenilinmediated modulation of capacitative calcium entry. Neuron 2000, 27, 561-572. [CrossRef]

147. Herms, J.; Schneider, I.; Dewachter, I.; Caluwaerts, N.; Kretzschmar, H.; Van Leuven, F. Capacitive calcium entry is directly attenuated by mutant presenilin-1, independent of the expression of the amyloid precursor protein. J. Biol. Chem. 2003, 278, 2484-2489. [CrossRef]

148. Akbari, Y.; Hitt, B.D.; Murphy, M.P.; Dagher, N.N.; Tseng, B.P.; Green, K.N.; Golde, T.E.; LaFerla, F.M. Presenilin regulates capacitative calcium entry dependently and independently of gamma-secretase activity. Biochem. Biophys. Res. Commun. 2004, 322, 1145-1152. [CrossRef] [PubMed]

149. Bojarski, L.; Pomorski, P.; Szybinska, A.; Drab, M.; Skibinska-Kijek, A.; Gruszczynska-Biegala, J.; Kuznicki, J. Presenilin-dependent expression of STIM proteins and dysregulation of capacitative $\mathrm{Ca}^{2+}$ entry in familial Alzheimer's disease. Biochim. Biophys. Acta 2009, 1793, 1050-1057. [CrossRef]

150. Sun, S.Y.; Zhang, H.; Liu, J.; Popugaeva, E.; Xu, N.J.; Feske, S.; White, C.L.; Bezprozvanny, I. Reduced synaptic STIM2 expression and impaired store-operated calcium entry cause destabilization of mature spines in mutant presenilin mice. Neuron 2014, 82, 79-93. [CrossRef]

151. Zhang, H.; Sun, S.; Wu, L.; Pchitskaya, E.; Zakharova, O.; FonTacer, K.; Bezprozvanny, I. Store-operated calcium channel complex in postsynaptic spines: A new therapeutic target for Alzheimer's disease treatment. J. Neurosci. 2016, 36, 11837-11850. [CrossRef]

152. Pascual-Caro, C.; Berrocal, M.; Lopez-Guerrero, A.M.; Alvarez-Barrientos, A.; Pozo-Guisado, E.; Gutierrez-Merino, C.; Mata, A.M.; Martin-Romero, F.J. STIM1 deficiency is linked to Alzheimer's disease and triggers cell death in SH-SY5Y cells by upregulation of L-type voltage-operated $\mathrm{Ca}^{2+}$ entry. J. Mol. Med. 2018, 96, 1061-1079. [CrossRef]

153. Gazda, K.; Kuznicki, J.; Wegierski, T. Knockdown of amyloid precursor protein increases calcium levels in the endoplasmic reticulum. Sci. Rep. 2017, 7, 14512. [CrossRef] [PubMed]

154. Ludewig, S.; Herrmann, U.; Michaelsen-Preusse, K.; Metzdorf, K.; Just, J.; Bold, C.; Müller, U.C.; Korte, M. APPs $\alpha$ rescues impaired $\mathrm{Ca}^{2+}$ homeostasis in APP- and APLP2-deficient hippocampal neurons. Proc. Natl. Acad. Sci. USA 2021, 118, e2011506118. [CrossRef] [PubMed]

155. Hartmann, J.; Karl, R.M.; Alexander, R.P.; Adelsberger, H.; Brill, M.S.; Ruhlmann, C.; Ansel, A.; Sakimura, K.; Baba, Y.; Kurosaki, T.; et al. STIM1 controls neuronal $\mathrm{Ca}^{2+}$ signaling, mGluR1-dependent synaptic transmission, and cerebellar motor behavior. Neuron 2014, 82, 635-644. [CrossRef]

156. Lv, M.M.; Cheng, Y.C.; Xiao, Z.B.; Sun, M.Y.; Ren, P.C.; Sun, X.D. Down-regulation of Homer1b/c attenuates group I metabotropic glutamate receptors dependent $\mathrm{Ca}^{2+}$ signaling through regulating endoplasmic reticulum $\mathrm{Ca}^{2+}$ release in PC12 cells. Biochem. Biophys. Res. Commun. 2014, 450, 1568-1574. [CrossRef] [PubMed]

157. Garcia-Alvarez, G.; Shetty, M.S.; Lu, B.; Yap, K.A.; Oh-Hora, M.; Sajikumar, S.; Bichler, Z.; Fivaz, M. Impaired spatial memory and enhanced long-term potentiation in mice with forebrain-specific ablation of the Stim genes. Front. Behav. Neurosci. 2015, 9, 180. [CrossRef] [PubMed]

158. Pascual-Caro, C.; Orantos-Aguilera, Y.; Sanchez-Lopez, I.; de Juan-Sanz, J.; Parys, J.B.; Area-Gomez, E.; Pozo-Guisado, E.; Martin-Romero, F.J. STIM1 Deficiency Leads to Specific Down-Regulation of ITPR3 in SH-SY5Y Cells. Int. J. Mol. Sci. 2020, 21, 6598. [CrossRef]

159. Kumar, U.; Dunlop, D.M.; Richardson, J.S. Mitochondria from Alzheimer's fibroblasts show decreased uptake of calcium and increased sensitivity to free radicals. Life Sci. 1994, 54, 1855-1860. [CrossRef]

160. Pizzo, P.; Lissandron, V.; Capitanio, P.; Pozzan, T. Ca ${ }^{2+}$ signalling in the Golgi apparatus. Cell Calcium 2011, 50, 184-192. [CrossRef]

161. Carreras-Sureda, A.; Pihan, P.; Hetz, C. Calcium signaling at the endoplasmic reticulum: Fine-tuning stress responses. Cell Calcium 2018, 70, 24-31. [CrossRef]

162. Martin, L.J. Mitochondrial and cell death mechanisms in neurodegenerative diseases. Pharmaceuticals 2010, 3, 839-915. [CrossRef] [PubMed]

163. Devine, M.J.; Kittler, J.T. Mitochondria at the neuronal presynapse in health and disease. Nat. Rev. Neurosci. 2018, 19, 63-80. [CrossRef] [PubMed]

164. Cárdenas, C.; Miller, R.A.; Smith, I.; Bui, T.; Molgo, J.; Muller, M.; Vais, H.; Cheung, K.H.; Yang, J.; Parker, I.; et al. Essential regulation of cell bioenergetics by constitutive InsP3 receptor $\mathrm{Ca}^{2+}$ transfer to mitochondria. Cell 2010, 142, 270-283. [CrossRef]

165. Rossi, A.; Pizzo, P.; Filadi, R. Calcium, mitochondria and cell metabolism: A functional triangle in bioenergetics. Biochim. Biophys. Acta Mol. Cell. Res. 2018, 1866, 1068-1078. [CrossRef] [PubMed] 
166. Pierrot, N.; Ghisdal, P.; Caumont, A.S.; Octave, J.N. Intraneuronal amyloid-beta1-42 production triggered by sustained increase of cytosolic calcium concentration induces neuronal death. J. Neurochem. 2004, 88, 1140-1150. [CrossRef]

167. Al-Mousa, F.; Michelangeli, F. Some commonly used brominated flame retardants cause $\mathrm{Ca}^{2+}$-ATPase inhibition, beta-amyloid peptide release and apoptosis in SH-SY5Y neuronal cells. PLoS ONE 2012, 7, e33059. [CrossRef] [PubMed]

168. Linde, C.I.; Baryshnikov, S.G.; Mazzocco-Spezzia, A.; Golovina, V.A. Dysregulation of $\mathrm{Ca}^{2+}$ signaling in astrocytes from mice lacking amyloid precursor protein. Am. J. Physiol. Cell Physiol. 2011, 300, C1502-C1512. [CrossRef]

169. Ronco, V.; Grolla, A.A.; Glasnov, T.N.; Canonico, P.L.; Verkhratsky, A.; Genazzani, A.A.; Lim, D. Differential deregulation of astrocytic calcium signalling by amyloid- $\beta, \mathrm{TNF} \alpha$, IL-1 $\beta$ and LPS. Cell Calcium 2014, 55, 219-229. [CrossRef]

170. Maccioni, R.B.; Gonzalez, A.; Andrade, V.; Cortes, N.; Tapia, J.P.; Guzman-Martinez, L. Alzheimer's disease in the perspective of neuroimmunology. Open Neurol. J. 2018, 12, 50-56. [CrossRef]

171. Hodges, A.; Strand, A.D.; Aragaki, A.K.; Kuhn, A.; Sengstag, T.; Hughes, G.; Elliston, L.A.; Hartog, C.; Goldstein, D.R.; Thu, D.; et al. Regional and cellular gene expression changes in human Huntington's disease brain. Hum. Mol. Genet. 2006, 15, 965-977. [CrossRef] [PubMed]

172. Wu, J.; Shih, H.P.; Vigont, V.; Hrdlicka, L.; Diggins, L.; Singh, C.; Mahoney, M.; Chesworth, R.; Shapiro, G.; Zimina, O.; et al. Neuronal store-operated calcium entry pathway as a novel therapeutic target for Huntington's disease treatment. Chem. Biol. 2011, 18, 777-793. [CrossRef] [PubMed]

173. Czeredys, M.; Gruszczynska-Biegala, J.; Schacht, T.; Methner, A.; Kuznicki, J. Expression of genes encoding the calcium signalosome in cellular and transgenic models of Huntington's disease. Front. Mol. Neurosci. 2013, 6, 42. [CrossRef] [PubMed]

174. Wu, J.; Ryskamp, D.A.; Liang, X.; Egorova, P.; Zakharova, O.; Hung, G.; Bezprozvanny, I. Enhanced store-operated calcium entry leads to striatal synaptic loss in a Huntington's disease mouse model. J. Neurosci. 2016, 36, 125-141. [CrossRef]

175. Wu, J.; Ryskamp, D.; Birnbaumer, L.; Bezprozvanny, I. Inhibition of TRPC1-dependent store-operated calcium entry improves synaptic stability and motor performance in a mouse model of Huntington's disease. J. Huntingt. Dis. 2018, 7, 35-50. [CrossRef]

176. Czeredys, M. Dysregulation of Neuronal Calcium Signaling via Store-Operated Channels in Huntington's Disease. Front. Cell. Dev. Biol. 2020, 8, 611735. [CrossRef]

177. Vigont, V.A.; Zimina, O.A.; Glushankova, L.N.; Kolobkova, J.A.; Ryazantseva, M.A.; Mozhayeva, G.N.; Kaznacheyeva, E.V. STIM1 protein activates store-operated calcium channels in cellular model of Huntington's disease. Acta Nat. 2014, 6, 40-47. [CrossRef]

178. Vigont, V.; Kolobkova, Y.; Skopin, A.; Zimina, O.; Zenin, V.; Glushankova, L.; Kaznacheyeva, E. Both Orai1 and TRPC1 are involved in excessive store-operated calcium entry in striatal neurons expressing mutant huntingtin exon 1. Front. Physiol. 2015, 6, 337. [CrossRef]

179. Baba, A.; Yasui, T.; Fujisawa, S.; Yamada, R.X.; Yamada, M.K.; Nishiyama, N.; Matsuki, N.; Ikegaya, Y. Activity-evoked capacitative $\mathrm{Ca}^{2+}$ entry: Implications in synaptic plasticity. J. Neurosci. 2003, 23, 7737-7741. [CrossRef]

180. Calì, T.; Ottolini, D.; Brini, M. Calcium signaling in Parkinson's disease. Cell Tissue Res. 2014, 357, 439-454. [CrossRef] [PubMed]

181. Stefani, I.C.; Wright, D.; Polizzi, K.M.; Kontoravdi, C. The role of ER stress-induced apoptosis in neurodegeneration. Curr. Alzheimer Res. 2012, 9, 373-387. [CrossRef]

182. Chan, C.S.; Guzman, J.N.; Ilijic, E.; Mercer, J.N.; Rick, C.; Tkatch, T.; Meredith, G.E.; Surmeier, D.J. “Rejuvenation” protects neurons in mouse models of Parkinson's disease. Nature 2007, 447, 1081-1086. [CrossRef] [PubMed]

183. Sun, Y.; Zhang, H.; Selvaraj, S.; Sukumaran, P.; Lei, S.; Birnbaumer, L.; Singh, B.B. Inhibition of L-Type Ca ${ }^{2+}$ Channels by TRPC1-STIM1 Complex Is Essential for the Protection of Dopaminergic Neurons. J. Neurosci. 2017, 37, 3364-3377. [CrossRef] [PubMed]

184. Liu, Y.; Harding, M.; Pittman, A.; Dore, J.; Striessnig, J.; Rajadhyaksha, A.; Chen, X. Cav1.2 and Cav1.3 L-type calcium channels regulate dopaminergic firing activity in the mouse ventral tegmental area. J. Neurophysiol. 2014, 112, 1119-1130. [CrossRef]

185. Li, X.; Chen, W.; Zhang, L.; Liu, W.B.; Fei, Z. Inhibition of store-operated calcium entry attenuates MPP(+)-induced oxidative stress via preservation of mitochondrial function in PC12 cells: Involvement of Homer1a. PLoS ONE 2013, 8, e83638. [CrossRef] [PubMed]

186. Sun, Y.; Sukumaran, P.; Singh, B.B. Sigma1 Receptor Inhibits TRPC1-Mediated Ca ${ }^{2+}$ Entry That Promotes Dopaminergic Cell Death. Cell. Mol. Neurobiol. 2021, 41, 1245-1255. [CrossRef]

187. Selvaraj, S.; Sun, Y.; Watt, J.A.; Wang, S.; Lei, S.; Birnbaumer, L.; Singh, B.B. Neurotoxin-induced ER stress in mouse dopaminergic neurons involves downregulation of TRPC1 and inhibition of AKT/mTOR signaling. J. Clin. Investig. 2012, 122, $1354-1367$. [CrossRef]

188. Tedeschi, V.; Petrozziello, T.; Secondo, A. Calcium Dyshomeostasis and Lysosomal Ca ${ }^{2+}$ Dysfunction in Amyotrophic Lateral Sclerosis. Cells 2019, 8, 1216. [CrossRef]

189. Kawamata, H.; Ng, S.K.; Diaz, N.; Burstein, S.; Morel, L.; Osgood, A.; Sider, B.; Higashimori, H.; Haydon, P.G.; Manfredi, G.; et al. Abnormal intracellular calcium signaling and SNARE-dependent exocytosis contributes to SOD1G93A astrocyte-mediated toxicity in amyotrophic lateral sclerosis. J. Neurosci. 2014, 34, 2331-2348. [CrossRef]

190. Goswami, A.; Jesse, C.M.; Chandrasekar, A.; Bushuven, E.; Vollrath, J.T.; Dreser, A.; Katona, I.; Beyer, C.; Johann, S.; Feller, A.C.; et al. Accumulation of STIM1 is associated with the degenerative muscle fibre phenotype in ALS and other neurogenic atrophies. Neuropathol. Appl. Neurobiol. 2015, 41, 304-318. [CrossRef] 